\title{
IS SIMILARITY A CONSTRAINT FOR SERVICE-TO-SERVICE BRAND
}

\section{EXTENSIONS?}

\section{RADU DIMITRIU*}

Associate Professor in Marketing,

Trinity Business School,

Trinity College Dublin,

Dublin 2, D02 F6N2, Ireland

Adjunct Associate Professor II, University of South-Eastern Norway, USN School of Business, Drammen, Norway

radu.dimitriu@tcd.ie, $+35318968227$

\section{LUK WARLOP}

Professor of Marketing, Department of Marketing, BI Norwegian Business School, Nydalsveien 37, 0484 Oslo, Norway

luk.warlop@,bi.no, $+4746410151$

Keywords: brand extensions, service associations, service brands, product brands, service quality, fit

Dimitriu, Radu and Luk Warlop (2021), "Is Similarity a Constraint for Service-to-Service Brand Extensions?", International Journal of Research in Marketing, in press, doi: https://doi.org/10.1016/j.ijresmar.2021.12.001.

Acknowledgements: The authors wish to acknowledge the Editor-in-Chief, the Associate Editor and the IJRM reviewers for their constructive and insightful feedback throughout the review process. The authors also acknowledge the financing of Study 3 by Flemish Research Council (FWO) grant G.0396.10 to Luk Warlop. 


\title{
IS SIMILARITY A CONSTRAINT FOR SERVICE-TO-SERVICE BRAND EXTENSIONS?
}

\begin{abstract}
Are service brands constrained in launching new service offerings? Both research evidence and managerial wisdom suggest brands should extend to similar categories. However, in five studies using real-life brands - four experiments and one large-sample survey - we provide evidence that similarity is less of a constraint for service brands extending to other service categories (service-to-service extensions), compared to cases involving parent brands or extension categories of a product nature. Importantly, we demonstrate that such an effect occurs because service brands possess associations relevant across the spectrum of service categories. Our results suggest that service brand managers have the opportunity to stretch their brands to dissimilar service offerings; yet, they need to ensure the marketing execution does not make the brands' service associations inaccessible to consumers. The findings suggest that even product brands can build service associations by adding service components to their offering, thus becoming "servitized" and better able to extend to dissimilar service categories. Overall, our work contributes to the academic debate documenting that the principles governing the management of product vs. service brands are not identical.
\end{abstract}

Keywords: brand extensions, service associations, service brands, product brands, service quality, fit 


\section{Introduction}

Brand extensions are a popular strategy for launching new market offerings (Keller 2008, Völckner and Sattler 2006). Three decades of research focused on consumer brand extensions have shed light on a variety of factors that can affect extensions' acceptance by consumers and their likely market success (Aaker and Keller 1990; Mathur, Jain, and Maheswaran 2012; Parker et al. 2018). Among these factors, the degree of fit, understood as the similarity between the parent brand and the extension category, repeatedly emerges as a critical determinant. A general principle holds that brands should move into similar categories (e.g., Harley Davidson motorcycle riding accessories) but avoid moving into dissimilar ones (e.g., Harley Davidson wine coolers) (Boush and Loken 1991; Park, Milberg, and Lawson 1991; Völckner and Sattler 2007).

Yet even as many examples confirm this principle, some exceptions puzzle observers. For example, the Virgin brand has expanded into categories as varied as airlines, mobile telephony, financial services, cruises, media, festivals, and fitness clubs (www.virgin.com). The Easy Group spans domains as diverse as airlines, gyms, hotels, real estate, van rentals, and pizza deliveries (www.easy.com). Under the umbrella of the Co-operative brand, we find food retailing, insurance, funeral care, and legal services (www.co-operative.coop). Why and how do such brand extensions into dissimilar categories succeed, if brands should focus on similar categories? One can observe that the brands we just listed are primarily thought of as service brands; the diverse categories where they operate are of a service nature as well. Such brands have also encountered failure with their extensions, for instance when Virgin introduced cola, vodka, bridal wear, cosmetics, or apparel (Business Insider 2012). However, the extensions that Virgin failed with tended to entail product (rather than service) domains.

Services make a significant share of the economy, e.g., $77.3 \%$ of the US GDP and $66.1 \%$ of the EU GDP (World Bank 2020); however, the literature has largely investigated 
extensions of product rather than of service brands. In this work, we suggest that the market success of extensions of service brands into other, distant service categories might be accounted for by reconsidering what constitutes "fit" in a brand extension context. Most literature defines fit as the similarity between a parent brand and an extension category (Dimitriu, Warlop, and Samuelsen 2017; Völckner and Sattler 2007; Yeo and Park 2006). Nevertheless, extensions to dissimilar categories might also be perceived to fit if the parent brand associations deliver benefits relevant to the extension category (Broniarczyk and Alba 1994; Monga and Gürhan-Canli 2012; Spiggle, Nguyen, and Caravella 2012). The current work is the first to demonstrate that this principle applies for the case of service brands stretching to dissimilar service offerings. Our rationale critically builds on the service quality literature, according to which high quality service providers might offer benefits that transcend the content of their service operation and apply to distinct service domains (Brady and Cronin 2001; Parasuraman, Zeithaml, and Berry 1985, 1988). Consider Vodafone, a mobile telephony operator. Because it is primarily a service rather than a product brand, the associations that consumers hold of Vodafone include the interaction with its front-end service personnel, the physical environment (i.e., shops) in which it renders sales and other mobile telephony services, or the online environment (website) with similar functions. Moreover, as primarily a service provider, Vodafone is linked to delivering service outcomes, attained through service encounters. Even for dissimilar extensions such as banking or travel services, Vodafone could arguably leverage strong positions on transcending associations as the ones exemplified above to extend its range of branded services, across heterogeneous service categories.

Therefore, we argue that the degree of similarity is less of a constraint for extensions of service brands into other service categories (i.e., service-to-service extensions) compared with extensions involving parent brands or extension categories of a product nature. We also 
make the case that low similarity service-to-service extensions fare better than low similarity extensions involving product dimensions, because service brands possess associations that are relevant across the spectrum of service categories, irrespective of the degree of similarity to the parent brand. Overall, we maintain that such service-specific associations play an essential role for service-to-service brand extensions. To establish these arguments, we start by locating our study within the context of brand extension literature, including the research stream dedicated to service brand extensions. We also review the conceptualizations of brand extension fit as similarity and association relevance respectively and relate this distinction to research done on service quality. Based on these conceptual insights, we derive hypotheses that we systematically test through five empirical studies (four experiments and one survey). We conclude with a critical discussion of the results and of our research contributions, along with key implications for managerial practice. Finally, we note some limitations of the current work and the avenues it opens for further research.

\section{Theoretical background}

Starting with Aaker and Keller's (1990) seminal work on brand extensions, researchers have provided continuing evidence that brand extension evaluations and their likely market success depend on characteristics of the parent or extending brand (Dacin and Smith 1994; Miniard et al. 2018; Torelli and Ahluwalia 2012), individual characteristics and predispositions (Cutright, Bettman, and Fitzsimons 2013; Kim and Park 2019; Mathur et al. 2012), contextual factors (Hansen, Kutzner, and Wänke 2013; Lehmann et al. 2007; Meyvis, Goldsmith, and Dhar 2012), or the marketing execution and mix (Monga and John 2010; Parker et al. 2018; Taylor and Bearden 2002). A common finding indicates that perceived fit between the parent brand and the extension category constitutes a key driver of brand extension success (Mao and Shanker Krishnan 2006; Park et al. 1991; Sichtmann and Diamantopoulos 2013). Studies of the relative importance of different drivers of brand 
extension success also indicate that fit is the most critical one (Völckner and Sattler 2006, 2007). With the caution that most of these investigations focus on extensions of products or tangible goods, a number of studies (e.g., de Ruyter and Wetzels 2000; Pina et al. 2006) explicitly investigate brand extensions involving services (please see Appendix A for a review of representative studies). Such studies (e.g., Hem, de Chernatony, and Iversen 2003; Sichtmann et al. 2017; van Riel, Lemmink, and Ouwersloot 2001) motivate their research focus by drawing on the innate differences between products and services, for instance the "SHIP" characteristics of simultaneity, heterogeneity, intangibility, and perishability (Iacobucci and Ostrom 1996), or consumers' need to rely on brand reputation rather than concrete attributes to evaluate service vs. product offerings (Berry 2000; Zeithaml, Berry, and Parasuraman 1996). In general, early research on service brand extensions indicates that the principles consumers apply to evaluate brand extensions in a product context also operate in a service context (Hem et al 2003; Martinez and Pina 2005; van Riel et al 2001), for example the fact that fit and parent brand quality are key drivers of service extension evaluations as well (Aaker and Keller 1990).

Yet Völckner et al. (2010) offer a contrasting view, when they specifically reconsider the role of fit and parent brand quality in driving evaluations of extensions of service brands to other service categories. They adopt Brady and Cronin's (2001) operationalization of quality, which is specific to the service domain and incorporates consumers' evaluations of service outcomes, interactions with service employees, and the service delivery environment. One of their findings is that, for service brands extending into other service categories, each of these quality assessments (outcome, interaction, and service environment) of the extension depends most on the parallel quality of the parent brand. This result implies that parent service brands possess associations that they can apply to extensions in various service categories, because associations with outcome, interaction, or service environment quality are 
desirable in general and applicable to various service settings. Such a notion resonates with the early work of Parasuraman et al. $(1985,1988)$, who introduced the service quality dimensions of tangibles, reliability, responsiveness, assurance, and empathy. These scholars regard service quality as a global evaluation, similar to attitudes, and assert that "regardless of the type of service, consumers use basically the same general criteria in arriving at an evaluation of service quality" (Parasuraman et al. 1988, p. 6).

The ability of a service brand to apply its associations to other service categories should inform our understanding of the concept of brand extension fit. A perception of fit might emerge in two distinct ways. First, fit reflects the degree of similarity or relatedness between the parent brand and the extension category, a conceptualization embraced by most brand extension scholars (Boush and Loken 1991; Dimitriu et al. 2017; Völckner and Sattler 2007). This fit-as-similarity perspective suggests that brands should extend to categories to which they are similar and that are close to their base, e.g., Colgate extended into mouthwash or Samsung extended into tablet computers. Alternatively, perceptions of fit might emerge if a brand's existing associations deliver relevant benefits in the extension category (Broniarczyk and Alba 1994; Monga and Houston 2002; Spiggle et al. 2012). Such a fit-asrelevance perspective suggests that brands can even extend to dissimilar categories if they possess associations that deliver benefits in those categories. In the product domain, extensions such as Caterpillar boots or Coca-Cola lip balms offer pertinent examples. The rationale that fit perceptions can emerge in two distinct ways is rooted in seminal categorization literature. On the one hand, fit-as-similarity implies that inferences about new category members (e.g., new brand extensions) are drawn based on the degree to which attributes are shared between a new category instance and the category as a whole (Rosch and Mervis, 1975; Tversky, 1977). On the other hand, fit-as-relevance involves the assessment of 
the degree to which a new category member has attributes that are regarded as valuable in the category (Loken and Ward, 1987; 1990).

For services, we propose that service brands are able to use transcending attributes (e.g., such as attributes underlying service quality perceptions) and apply them as relevant benefits in other service categories, irrespective of the degree of similarity. Thus, we expect the degree of similarity between the parent brand and the extension category to be less of a constraint to evaluations of service-to-service brand extensions compared to extensions involving parent brands or extension categories of a product nature. We also expect dissimilar service-to-service extensions to fare better compared to dissimilar extensions involving product dimensions, given that service brands possess associations that can be relevant across disparate service offerings. We test these predictions through three initial empirical studies. Study 1 is an experiment where we compare extensions of the same service brand into either product or service categories matched as either low or high on similarity to the parent brand. In Study 2 we compare experimentally matched low vs. high similarity extensions into the same service category, originating from either product or service brands. Study 3 is a largesample survey where consumers evaluated different real-life brand extensions, their degree of similarity, and the extent to which the respective parent brands and extension categories stood for either products or services. Two subsequent experimental studies provide direct evidence for the role that service-specific associations play in the evaluation of service-to-service extensions by manipulating the presence (Study 4) and the accessibility (Study 5) of such associations.

Starting with Study 1, we compare extensions of a service brand to either service or product categories, as exemplified previously by the efforts of the Virgin brand. Research on service quality (Brady and Cronin 2001; Parasuraman et al. 1988) and service-to-service brand extensions (Völckner et al. 2010) suggests that service brand attributes can be 
leveraged across a wide array of categories. For example, employee friendliness and expertise; the ambience, design, and functionality of the physical and online service delivery environments; and the promptness or quality of the service experience all provide relevant benefits in both similar and dissimilar service categories (cf., Broniarczyk and Alba 1994; Spiggle et al. 2012). Yet such attributes may be less pertinent in product domains, so similarity should remain an important evaluation criterion for service-to-product extensions. Formally:

H1: Similarity affects brand extension evaluation significantly less when a service brand extends into services, rather than into products.

In more detail, we argue that perceptions of the relevance of the parent brand's associations may emerge even for distant extensions of a service brand into other service categories (cf., Monga and Houston 2002; Spiggle et al. 2012), because service brands are imbued with attributes applicable across service categories (Brady and Cronin 2001; Parasuraman et al. 1988). Such attributes aid consumers' evaluations of a service brand extending into a dissimilar service category, but they cannot salvage evaluations of a service brand extending into a dissimilar product category. Therefore,

H2: Brand extension evaluation is (a) higher for a service brand extending into a low similarity service category compared with a low similarity product category, because (b) the service brand possesses associations that are relevant for the low similarity service category, but not for the low similarity product category.

We test these predictions in Study 1 below.

\section{Study 1}

In Study 1 we asked consumers to evaluate extensions of a service brand into product and service categories, varying in their degree of similarity to the brand. We orthogonally manipulated the nature of the extension category (product vs. service) and the similarity 
between the parent brand and the extension category (low vs. high) in a $2 \times 2$ betweensubjects experimental design. The dependent variable was brand extension evaluation. Our theoretical discussion suggests that service brands possess service-specific associations that are relevant for extensions into service categories (irrespective of the degree of similarity). Therefore, we also asked participants to assess how relevant the parent brand associations were for the extension category (which we term "association relevance").

\subsection{Method}

The chosen parent brand was Vodafone, a well-known provider of mobile telephony services. We pretested 12 extension categories, six with a predominantly service nature and six with a product nature. 28 pretest participants rated the similarity between the parent brand and the extension categories on three items $(1=$ "Totally disagree" to $7=$ "Totally agree": “[Extension category] is similar to Vodafone's current offerings," “[Extension category] is similar to the associations I have for the brand Vodafone," and "[Extension category] is similar to the brand image of Vodafone", cf., Dacin and Smith 1994; Park et al. 1991). For the main experiment, we retained four categories: online music streaming (service, high similarity), banks (service, low similarity), car GPS devices (product, high similarity), and skateboards (product, low similarity). The results of the pretest indicated that skateboards and banks $\left(M S=1.88, M_{B}=2.12, t(27)=-1.22, p>.2\right)$ and car GPS devices and online music streaming $\left(M_{C}=4.39, M_{O}=4.90, t(27)=-1.72, p>.09\right)$ do not differ significantly in their similarity to Vodafone. The similarity score for car GPS devices was higher than the value for either banks $\left(M_{C}=4.39, M_{B}=2.12, t(27)=6.03, p<.01\right)$ or skateboards $\left(M_{S}=1.88, t(27)\right.$ $=7.26, p<.01)$; that for online music streaming was higher than those for both banks $(M o=$ 4.90, $\left.M_{B}=2.12, t(27)=8.64, p<.01\right)$ and skateboards $\left(M_{S}=1.88, t(27)=10.66, p<.01\right)$.

The sample for the Study 1 consisted of 97 students of a UK university (mean age $=$ 26.92 years, $46.4 \%$ women), randomly assigned to one of the four conditions. Upon logging 
in to an online survey, participants read about the Vodafone brand and saw the brand's logo. A second screen described Vodafone's plans to enter one of the four categories and asked participants to evaluate the brand extension $(1=$ "Totally disagree" to $7=$ "Totally agree": "I would have a favorable attitude towards the Vodafone [brand extension]" and "I think it is a good idea for Vodafone to launch a [brand extension]”, $\alpha=.91$, Barone 2005; Park et al. 1991). They also rated the brand's association relevance for the extension category $(1=$ "Totally disagree"/ 7 = "Totally agree" to "There are things that I associate with Vodafone that can be relevant for [extension category]"). The manipulation check gauged the similarity perceptions (same measures as in the pretest, $\alpha=.90$ ), and we also measured participants' familiarity with the extension category as a covariate.

\subsection{Results}

The similarity manipulation check confirmed that the manipulation of the similarity factor worked as intended $(F(1,93)=17.04, p<.01)$, without any influence of the nature of the extension category or the interaction of the two factors ( $p$ 's $>.4)$. We thus reconfirmed our use of skateboards and banks for the low similarity conditions, and respectively of car GPS devices and online music streaming for the high similarity conditions.

The ANCOVA analysis on brand extension evaluation as dependent variable found a main effect of similarity $(F(1,92)=13.17, p<.01)$. The nature of the extension category did not have a significant main effect $(F(1,92)=.02, p>.9)$, however it qualified the impact of similarity on brand extension evaluation $(F(1,92)=5.12, p<.03)$. Planned contrasts revealed that similarity influenced evaluations of the service-to-product extensions but not service-toservice extensions. As we detail in Figure 1, the evaluation of the Vodafone skateboard was significantly worse than that of the Vodafone car GPS (3.15 vs. 4.98, $F(1,92)=15.24, p<$ .01 ), whereas the evaluations of the Vodafone bank and online music streaming service did not differ significantly (3.82 vs. $4.23, F(1,92)=.99, p>.3)$, supporting H1. 
(Figure 1)

The planned contrast of the evaluations of the low similarity product versus service extensions (skateboard vs. bank) did not reach significance at conventional levels (3.15 vs. $3.82, F(1,92)=2.23, p=.13)$, and nor did the parallel contrast of the high similarity product versus service extensions (car GPS vs. online music streaming) $(4.98$ vs. $4.23, F(1,92)=$ $2.30, p=.13)$. The lack of difference in evaluations of the low similarity extensions fails to offer support for H2a. However, the nature of the low similarity extensions (product vs. service) could still influence evaluations indirectly, through association relevance (Zhao, Lynch, and Chen 2010). As shown in Figure 2, the ANCOVA analysis on association relevance revealed a pattern similar to that for brand extension evaluation as dependent variable:

(Figure 2)

In mediation tests based on bootstrapping (Hayes and Preacher 2010; Zhao et al. 2010), we sought to ascertain if the nature of the extension category exerted an indirect impact on brand extension evaluation through association relevance. As expected, this was the case for the low similarity conditions: the bootstrapping analysis based on 5,000 subsamples found a significant indirect effect $\left(\beta_{\text {indirect }}=.54 ; 95 \% \mathrm{CI}: .03\right.$ to 1.27$)$; the direct effect was insignificant $\left(\beta_{\text {direct }}=.37, p>.4\right)$, suggesting full mediation. Thus, we find support for $H 2 b$. Interestingly, we also found mediation evidence for the high similarity conditions: the indirect effect in this case was also significant $\left(\beta_{\text {indirect }}=-.60 ; 95 \% \mathrm{CI}:-1.23\right.$ to -.17$)$ while the direct effect was insignificant $\left(\beta_{\text {direct }}=-.18, p>.6\right)$, suggesting full mediation.

\subsection{Discussion}

The results support our hypothesis that similarity influences evaluations significantly less when a service brand extends into services rather than into products. For service-toproduct extensions, Study 1 finds the low similarity extension gets a poorer evaluation than 
the high similarity extension. For service-to-service cases, the evaluations of the low and high similarity extensions do not differ significantly. This pattern of results repeats when we use association relevance as the dependent variable. For low similarity extensions of a service brand, we also find that the nature of the extension category (product vs. service) influences brand extension evaluations indirectly, through association relevance. This result lends support to our conjecture that service brands possess associations that prove beneficial in dissimilar service domains but not in dissimilar product domains (e.g., Vodafone bank vs. Vodafone skateboard). Our theorizing did not lead us to predict different evaluations between the high similarity conditions, but Study 1 finds that association relevance explains the difference between the high similarity service-to-product extension (Vodafone GPS) and the high similarity service-to-service extension (Vodafone online music streaming). We return to this less expected result in the general discussion.

With Study 2, we seek to take a different angle on our general prediction that similarity is less of a constraint for service-to-service extensions than for extensions involving product dimensions. Specifically, we consider brand extensions into the same service category, but we vary the nature of the parent brands and their degree of similarity to the extension category. The theoretical expectations reflect the same conceptual foundations we established for Study 1. In particular, service brands likely possess attributes that benefit a range of service domains (Brady and Cronin 2001; Parasuraman et al. 1988), irrespective of the degree of similarity. Conversely, product brands aiming to extend to service domains are not endowed with such associations, and need to achieve a high degree of similarity to get high ratings of their product-to-service extensions. Formally:

H3: Similarity affects brand extension evaluation significantly less when service brands, rather than product brands, extend to a service category. 
Also in line with our prior reasoning, perceptions that a parent brand offers relevant associations for a dissimilar service category may be more likely if the parent brand also is a service (Monga and Houston 2002; Spiggle et al. 2012); such perceptions may boost evaluations of a low similarity service-to-service extension. However, such perceptions are less likely if consumers evaluate extensions of a product brand to a dissimilar service domain. We therefore predict that:

H4: For a service extension category, (a) a low similarity extension by a service brand is evaluated better than a low similarity extension by a product brand, because (b) the service brand possesses associations that are more relevant to the service extension category.

\section{Study 2}

To test these parallel predictions, we asked participants to evaluate brand extensions to the same service category, in an experiment with a 2 (nature of the parent brand: product vs. service $) \times 2$ (similarity between the parent brand and the extension category: low vs. high) between-subjects design. Brand extension evaluation was the dependent variable; we again captured a measure of association relevance, specifically probing if the parent brand in each condition had the necessary service credentials for the extension category.

\subsection{Method}

The extension category, online medical services (i.e., services of connecting patients with doctors for online video consultations), remained constant across conditions. We ran a pretest with 22 brands, each rated by different participants in terms of their similarity to the online medical services category (using the measures from Study 1) and the degree to which these brands represent product or service brands (one item). From this pretest, we identified four brands: Admiral (car insurance: service, low similarity), Aviva (medical insurance: service, high similarity), HP (computers and accessories: product, low similarity), and Pfizer (pharmaceuticals: product, high similarity). The results of the pretest indicated that both 
Admiral and HP were perceived as just as low on similarity to online medical services $\left(M_{\text {Admiral }}=2.96, M_{H P}=2.72, t(59)=.63, p=.53\right)$, while Aviva and Pfizer were perceived as just as high on similarity to such services $\left(M_{\text {Aviva }}=3.71, M_{\text {Pfizer }}=3.83, t(57)=-.26, p=.72\right)$. In addition, the similarity score for Aviva was higher than those for Admiral $(t(57)=1.91, p=$ $.06)$ or HP $(t(58)=3.14, p<.01)$, as was that for Pfizer (cf. Admiral $t(58)=2.34, p<.05$; cf. HP $t(59)=3.82, p<.01)$.

We also ensured the stimuli reflect the nature of the parent brand (product vs. service) effectively. In the pretest, we explained that brands might represent pure product manufacturers, pure service providers, or some combination of both. Then we asked respondents to rate the brands on a scale of $1=$ "Pure product" to $7=$ "Pure service." Both HP and Pfizer were rated as product rather than service brands, to similar extents $(M H P=$ 3.06, MPfizer $=3.27, t(59)=-.54, p=.59)$; Admiral and Aviva represented service rather than product brands, also to similar extents $\left(M_{\text {Admiral }}=5.90, M_{\text {Aviva }}=6.00, t(57)=-.37, p=.71\right)$. In addition, Admiral scored higher than both $\operatorname{HP}(t(59)=9.25, p<.01)$ and Pfizer $(t(58)=7.39$, $p<.01$ ), as did Aviva (cf. HP $t(58)=9.94, p<.01$; cf. Pfizer $t(57)=7.85, p<.01)$.

In the main $2 \times 2$ between-subjects experiment, we obtained the participation of 400 Prolific (prolific.co) participants (mean age $=36.25$ years, $76.8 \%$ women). As in Study 1 , each respondent was randomly assigned to one of the four conditions in the online survey, then saw a short introduction of the brand and its logo. They read the company was planning to launch a new online medical services business. On the next screen, participants rated the brand extension evaluation ( 1 = "Strongly disagree" to 7 = "Strongly agree": "I would have a favorable attitude towards [brand] online medical services", "I think it is a good idea for [brand] to launch online medical services" and "I think that [brand] would be a provider of good quality online medical services", $\alpha=.91)$. We then gauged association relevance, asking whether the parent brand has the necessary service credentials to launch the service 
extension: "[Brand] would have good service provision credentials to use in a new online medical services business" ( $1=$ "Strongly disagree" to $7=$ "Strongly agree"). The questionnaire also contained manipulation checks for similarity and the nature of the parent brand, along with questions to assess parent brand attitude, parent brand familiarity, and extension category familiarity (to be used as covariates).

\subsection{Results}

The manipulation check confirmed that the similarity score depended only on whether the extension was low (HP, Admiral) or high (Pfizer, Aviva) in similarity $(F(1,396)=52.51$, $p<.001)$. The nature of the parent brand and the factor interaction did not affect the similarity score $(p ’ s>.21)$. The item measuring the nature of the parent brand was only affected significantly by the relevant factor $(F(1,396)=472.35, p<.001)$, and neither similarity nor the interaction of the two factors had significant effects ( $p$ 's $>.2)$.

The ANCOVA on brand extension evaluation revealed a significant main effect of similarity $(F(1,393)=7.35, p<.01)$. The main effect of the nature of the parent brand was also significant $(F(1,393)=.3, p<.05)$. As expected, we identified a significant factor interaction $(F(1,393)=6.26, p<.05)$. Planned contrasts suggested that similarity affected evaluations of the product-to-service extensions but not service-to-service extensions, as displayed in Figure 3. For extensions by product brands, Pfizer online medical services were evaluated significantly better than HP online medical services $(4.85$ vs. $4.24, F(1,393)=$ 13.34, $p<.01)$. However, for the service brands, Aviva and Admiral online medical services were evaluated just as positively $(4.84$ vs. $4.81, F(1,394)=.031, p>.8)$. We thus find support for H3.

(Figure 3)

The planned contrast tests for the low similarity extensions further revealed that Admiral online medical services were evaluated significantly better than HP online medical 
services $(4.81$ vs. $4.24, F(1,393)=12.30, p<.01)$, in support of $\mathrm{H} 4 \mathrm{a}$. The parallel test for the high similarity extensions found no significant difference between the evaluations of Aviva and Pfizer extensions (4.84 vs. 4.85, $F(1,393)=.002, p>.96)$. The ANCOVA on association relevance revealed a pattern similar to that for brand extension evaluations (Figure 4).

(Figure 4)

The bootstrapping tests to check if the nature of the parent brand drives brand extension evaluation through association relevance indicate, for the low similarity conditions, a significant indirect effect $\left(\beta_{\text {indirect }}=.3 ; 95 \%\right.$ CI: .09 to .54$)$ and an insignificant direct effect $\left(\beta_{\text {direct }}=.23, p>.09\right)$, suggesting full mediation. $\mathrm{H} 4 \mathrm{~b}$ is thus supported. In the high similarity conditions, the analysis reveals neither a significant indirect effect $\left(\beta_{\text {indirect }}=-.21,95 \% \mathrm{CI}\right.$ : .42 to .0005$)$ nor a significant direct effect $\left(\beta_{\text {direct }}=.18, p>.11\right)$.

\subsection{Discussion}

These results confirm that similarity has a weaker effect on brand extension evaluations when service brands, rather than product brands, extend into a particular service extension category. Study 2 finds that a high similarity extension by a product brand receives better evaluations than a low similarity extension by a product brand; however, both high and low similarity service-to-service extensions are evaluated equally well. Also, a low similarity extension into a service category is better evaluated when the parent brand exhibits more of a service rather than product nature. We provide evidence that such difference arises because, compared with a product brand, a service brand has a significantly greater ability to establish attributes that appear relevant in a dissimilar service category.

The preceding two experimental studies use hypothetical brand extensions of real-life brands, similar to most prior research on brand extensions (e.g., Cutright et al. 2013; Miniard et al. 2018; Völckner et al. 2010). Also, to ensure experimental control, these studies test the hypotheses with stimuli denoting either extensions of the same service brand (Study 1) or 
extensions to the same service category (Study 2). Yet using different real-life extensions of existing brands (e.g., Völckner and Sattler 2006, 2007) can ascertain whether the effects tested above also hold when consumers evaluate actually-launched brand extensions, and not just hypothetical ones. In Study 3 we collect consumers' evaluations of different real-life brand extensions, across parent brands and extension categories that span the product-service spectrum. The resulting evidence helps establish the external validity and practical relevance of our theoretical propositions.

Further, in the previous studies we compare service-to-service extensions against either service-to-product (Study 1) or product-to-service (Study 2) extensions. A potential alternative explanation for the results so far might be that brand extensions that keep to the same domain, i.e., service-to-service as well as product-to-product, generally benefit from domain-specific associations. Such an account would suggest similarity also has a lesser impact on the evaluation of product-to-product extensions, compared to brand extensions spanning domains; in addition, low similarity product-to-product extensions should fare better than low similarity extensions spanning domains. With Study 3, we seek to rule out this alternative explanation.

\section{Study 3}

Formally, in this large-sample survey, each participant evaluated one real-life brand extension. In Study 3, we tested whether similarity is less of a constraint for service-toservice brand extensions than for extensions involving parent brands or extension categories of a product nature ( $\mathrm{H} 1$ and $\mathrm{H} 3$ ); we also sought further evidence that low similarity serviceto-service brand extensions are better evaluated than low similarity extensions involving either a product brand or a product category $(\mathrm{H} 2 \mathrm{a}$ and $\mathrm{H} 4 \mathrm{a})$, given the role played by associations that are relevant across service categories ( $\mathrm{H} 2 \mathrm{~b}$ and $\mathrm{H} 4 \mathrm{~b})$.

\subsection{Method}


For this online study, the 1,422 MTurk US-based participants (mean age $=36.03$ years, $49.6 \%$ women) each rated one, randomly assigned, real-life brand extension. Each participant rated one of 38 brand extensions originating from 29 parent brands; the list of 38 brand extensions was generated by researching and randomly selecting extensions undertaken by brands listed under the 500 most valuable brands in the US in 2016 (Brand Finance 2017). A separate pretest with 101 different MTurk participants confirmed that all the 29 parent brands included in the survey (see Table 1) scored at least 5.5 on a 1 ("not familiar at all") to 7 (“very familiar") scale.

(Table 1)

The dependent variable, brand extension evaluation, was measured with three semantic items as per Völckner and Sattler (2006): "How high or low do you perceive the quality of [extension] to be?" "To what extent do you agree with the statement 'The [extension] is a market success'?" and "How would you perceive the overall quality of [extension] relative to competing offerings in the market?" $(\alpha=.91)$. We also measured perceptions of parent brand association relevance. Because participants rated extensions to both services and products, we first used a non-domain-specific scale ("I think [brand] has attributes that can be useful for [extension category]," "There are things I associate with [brand] that can be relevant for [extension category]," and "[Brand] has associations that can prove important in the context of [extension category]", $\alpha=.96)$. Then, specifically for extensions into services, and consistent with our theorizing and previous studies, we measured the perception of whether the parent brand has relevant associations as service credentials for the extension category ("To what extent does [brand] have the service credentials for [extension category]?").

The measure of similarity matched that the previous studies $(\alpha=.95)$. Participants also rated the nature of the parent brand ( $1=$ "Pure product" to $7=$ "Pure service"); further, 
the extension categories were classified as either product (0) or service (1). As covariates, we measured parent brand attitude and familiarity, as well as extension category attitude, familiarity, and personal relevance to the participant. Table 2 contains the correlation matrix.

(Table 2)

\subsection{Results}

We tested the hypotheses with moderation and moderated mediation analyses based on bootstrapping, using templates in the Process macro (Hayes 2017). To start with, we used Model 3 to regress brand extension evaluations on similarity, nature of the parent brand, nature of the extension category, their two-way interactions, and their three-way interaction; the covariates also entered this model. The results suggested a significant three-way interaction effect between similarity, nature of the parent brand, and nature of the extension category on brand extension evaluations $\left(\beta_{3-\text { way }}=-.05, p<.01\right)$, which we analyze in distinct fashions below to provide tests of the hypotheses.

Test of H1: the impact of similarity on product vs. service extensions of service brands

First, the effect of similarity on brand extension evaluation is differently dependent on the nature of the extension category (product vs. service) at different levels of the parent brand being perceived to be product vs. service (scored from 1 to 7). In detail, the effect of similarity on evaluation depends on extension category nature when the nature of the parent brand is service rather product (brand nature score $=6.00,84 \%$ percentile $)\left(\beta_{2-w a y}=-.31\right.$, $F(1,1409)=48.5, p<.01)$, but not when the nature of the parent brand is product rather service (brand nature score $=1.00,16 \%$ percentile) $\left(\beta_{2-\text { way }}=-.06, F(1,1409)=1.58, p>\right.$ .21 ). When the parent brand nature is service rather than product (brand nature score $=6.00$, $84 \%$ percentile), the impact of similarity decreases significantly between the case when the extension category is of a product nature (extension category nature score $=0)\left(\beta_{\text {similarity }}=\right.$ 
$.48, p<.01)$, and the case when it is of a service nature (extension category nature score $=1$ ) $\left(\beta_{\text {similarity }}=.18, p<.01\right)$. Therefore, we again find support for $\mathrm{H} 1$.

Test of H3: the impact of similarity on service extensions of product vs. service brands Furthermore, the three-way interaction shows that the effect of similarity on brand extension evaluation depends differently on the nature of the parent brand (product vs. service, 1 to 7), dependent on whether the nature of the extension category is product or service $(0 / 1)$. When the extension category nature is product, we find a positive interaction effect between similarity and parent brand nature $\left(\beta_{2-w a y}=.03, F(1,1409)=16.21, p<.01\right)$; this interaction effect becomes negative when the extension category nature is service $\left(\beta_{2-\text { way }}=-.02, F(1,1409)=2.91, p<.1\right)$. Given a service extension category, the effect of similarity on evaluations decreases between the case when parent brand nature is product rather than service (brand nature score $=1.00,16 \%$ percentile) $\left(\beta_{\text {similarity }}=.27, p<.01\right)$ and the case when parent brand nature is service rather than product (brand nature score $=6.00$, $84 \%$ percentile $)\left(\beta_{\text {similarity }}=.18, p<.01\right)$. These results offer support for $\mathrm{H} 3$.

Test of H2a: the evaluation of low similarity product vs. service extensions of a service brand As a different way to look at the three-way interaction above, the interaction of the nature of the extension category and the nature of the parent brand has different effects on brand extension evaluation at distinct levels of brand extension similarity: significant at low levels of similarity $($ similarity score $=1.67,16 \%$ percentile $)\left(\beta_{2-\text { way }}=.15, F(1,1409)=\right.$ $14.52, p<.01$ ) but insignificant at high levels ( $\left(\beta_{2-\text { way }}=-.06, F(1,1409)=2.45, p>.1\right)$. Based on a spotlight analysis at low levels of brand extension similarity ( similarity score $=1.67,16 \%$ percentile), the effect of extending into a service rather than a product category is significant and positive $\left(\beta_{\text {nature } E C}=1.17, p<\right.$ .01 ) if the parent brand nature is service rather than product (brand nature score $=6.00,84 \%$ percentile), in line with $\mathrm{H} 2 \mathrm{a}$. 
Test of H4a: the evaluation of low similarity service extensions by a product vs. service brand

Another spotlight analysis at low levels of brand extension similarity (similarity score $=1.67,16 \%$ percentile) also reveals that the effect of the parent brand nature being service rather than product is significant and positive $\left(\beta_{\text {nature } P B}=.06, p<.06\right)$ when the extension category has a service nature. Therefore, we also find support for $\mathrm{H} 4 \mathrm{a}$. Test of H2b: the role of association relevance in driving the H2a effect

To test the role of association relevance in driving these effects, we also applied Model 11 in the Process macro with 5,000 bootstrap subsamples. For the non-domainspecific measure of association relevance, at low levels of similarity (similarity score $=1.67$, $16 \%$ percentile) and when the parent brand nature is service rather than product (brand nature score $=6.00,84 \%$ percentile), the impact of extending into a service rather than a product category through association relevance is significant $\left(\beta_{\text {indirect }}=.7 ; 95 \% \mathrm{CI} . .47\right.$ to .92$)$. We also find parallel evidence of mediation if we use the association relevance as service credentials measure $\left(\beta_{\text {indirect }}=.54 ; 95 \% \mathrm{CI} .4\right.$ to .7$)$; however, this measure might be less adequate to gauge association relevance for extensions into product domains, for which service credentials are less applicable. Overall though, we find support for H2b. Test of H4b: the role of association relevance in driving the H4a effect

Further using the non-domain specific measure of association relevance, at low levels of similarity ( similarity score $=1.67,16 \%$ percentile) and when the extension category is of a service nature, the impact of the parent brand nature being service rather than product, through association relevance, is non-significant $\left(\beta_{\text {indirect }}=.07 ; 95 \% \mathrm{CI}\right.$ : -.005 to .14$)$. The association relevance measure may however be less focused, as we specifically test the indirect effect for extensions into service categories. Still, a parallel analysis using the association relevance as service credentials measure reveals a significant indirect effect $\left(\beta_{\text {indirect }}=.13 ; 95 \% \mathrm{CI}: .09\right.$ to .16$)$, so we note support for $\mathrm{H} 4 \mathrm{~b}$. 
Ruling out the alternative explanation: focusing on product-to-product extension evaluation

We ran further analyses to test the alternative account that, like service-to-service extensions and unlike extensions spanning domains, the evaluation of product-to-product extensions might be less affected by similarity while benefitting from domain-specific associations. First, when the parent brand nature is product (brand nature score $=1.00,16 \%$ percentile), results suggest that the impact of similarity is actually stronger when the extension category is of a product nature $\left(\beta_{\text {similarity }}=.33, \mathrm{p}<.01\right)$ rather than of a service nature $\left(\beta_{\text {similarity }}=.27, \mathrm{p}<.01\right)$, albeit the difference is not significant $\left(\beta_{2-w a y}=-.06\right.$, $\mathrm{F}(1,1409)=1.58, \mathrm{p}>.21)$. Besides, contrary to what the above alternative account would predict, at low levels of similarity ( similarity score $=1.67,16 \%$ percentile) and when the parent brand nature is product (brand nature score $=1.00,16 \%$ percentile), the current data suggest that extensions into services score higher on association relevance $\left(\beta_{\text {nature_EC }}=.65\right.$, $\mathrm{p}<.01)$ and brand extension evaluation $\left(\beta_{\text {nature } E C}=.45, \mathrm{p}<.01\right)$ than extensions into products. Such results do not lend support to the alternative explanation highlighted above.

\subsection{Discussion}

With this large-sample survey, in which participants rated different real-life (rather than hypothetical) brand extensions, we still find that similarity has a weaker effect on evaluations of service-to-service brand extensions, compared with evaluations of extensions involving product dimensions (either service-to-product or product-to-service). Furthermore, low similarity service-to-service brand extensions are better evaluated than low similarity service-to-product or product-to-service extensions, as service brands hold associations that are relevant and applicable across service domains. Overall, the findings affirm the generalizability of the experimental results in Studies 1 and 2. Support for the hypotheses, obtained with real-life brands, also points to the practical applicability of the theoretical propositions. 
Study 3 results also allow ruling out the alternative explanation that brand extensions contained to the same domain generally benefit from domain-specific associations. Our theorizing and the results above support such an effect for service-to-service extensions, but not for product-to-product extensions. In this papers' general discussion, we debate why product brands might not have an inherent ability to leverage their associations across product domains, unlike service brands extending to service domains.

Studies 1 to 3 offer preliminary evidence that service brands possess associations which are relevant across the spectrum of service categories, irrespective of the degree of similarity to the parent brand. As per the mediation tests above, such associations also allow low similarity service-to-service brand extensions to fare better than low similarity extensions involving parent brands or extension categories of a product nature. However, with association relevance being measured in Studies 1 to 3, the evidence on the role of servicespecific associations is inherently correlational. In the subsequent studies, we provide direct evidence for the role such associations play for service-to-service extensions by explicitly manipulating their presence (Study 4) and their accessibility (Study 5).

In Study 4 we compare low similarity extensions to a service category by a product vs. a service brand. Whereas earlier mediation evidence (in Studies 2 and 3) suggested that "service credentials" can explain the difference in evaluations between such extensions, with Study 4 we seek to offer direct evidence of this mediating mechanism by manipulating it (cf., Spencer, Zanna, and Fong 2005). Specifically, we add service components to a product brand to endow it with service associations (i.e., "servitize" it), to then determine if it can extend as successfully as a service brand to a low similarity service category. Formally: H5: Evaluations are lower for a product brand than a service brand extending into a low similarity service category, but endowing the product brand with service associations 
("servitizing" it) results in equivalently high brand extension evaluations as result from the extension of the service brand.

Evidence in support of this hypothesis would establish that service attributes are the key mechanism that enable service brands to stretch to other service domains.

\section{Study 4}

To establish direct evidence of the role of associations specific to the service domain, we tested whether endowing a product brand with service associations ("servitizing" it) makes it appear more like a service brand and supports approval of its extension in a low similarity service category. To servitize a product brand, we presented Study 4 participants with a story describing that the brand was about to extend into a service offering (service story), compared to remaining in the same domain by extending into a product offering (product story). We further compared these conditions against another one that did not mention any imminent extension (no story). Simultaneously, we manipulated the nature of the parent/extending brand, so as to compare a product and a service brand that are equivalently low on similarity to the target extension service category where the extension was later attempted. Therefore, the experiment had a 2 (nature of the parent brand: product vs. service) $\times 3$ (story: no story vs. product story vs. service story) between-subjects design. The dependent variable was brand extension evaluation, and we also measured the perception of association relevance of the parent brand

\subsection{Method}

The participants evaluated extensions of either the product or the service brand into the target service category of electricity provision. This target category remained the same across experimental conditions. We ran a pretest with 34 participants, designed to select two parent (one product, one service) brands with equivalently low similarity to electricity provision. We identified the brands HP and Vodafone as suitable for such purpose. The 
pretest revealed that, compared with Vodafone, HP was perceived as a product brand and not a service brand $\left(M_{H P}=3.12, M_{\text {Vodafone }}=5.26, t(33)=5.75, p<.01\right)$, but the two brands did not appear significantly different in their similarity to the electricity provision service category $\left(M_{H P}=2.97, M_{\text {Vodafone }}=3.37, t(33)=1.57, p>.1\right)$.

The main experiment included 142 participants from a UK-based university (mean age $=27.4$ years, $45.8 \%$ women), randomly assigned to one of the six experimental conditions. On the first screen, participants saw the brand logo (either HP or Vodafone). Depending on the experimental condition, the second screen contained a screenshot of an article, describing the brand's plans to extend into either a product offering or a service offering, i.e., the preliminary story (Appendix B). These product or service stories, which we manipulated, were disguised as news appearing on the $\mathrm{BBC}$ website and kept as parallel as possible. The product story indicated the brand was about to launch an HP/Vodafone Connector router that could be installed in consumers' homes to integrate technology appliances; the service story reported on the imminent launch of an HP/Vodafone Connector team service that would visit consumers' homes to install the technology and offer advice on the best integration of technology appliances. Participants in the no story condition did not read any preliminary story. On the subsequent screen, participants read that the brand was considering launching an energy provision offering; subsequently, they rated brand extension evaluation (as in Study 1) and association relevance ("There would be things associated with HP/Vodafone that can be relevant for an electricity provider"; "HP/Vodafone would have good service provision credentials to use as a new electricity provider" on 7-point agreement scales, $\alpha=.76$ ). As manipulation checks, we first measured the similarity of the brand to electricity provision; further, we asked participants to discard the HP/Vodafone Connector news they might have read a few screens before, and rate their normal perception of the 
nature of the parent brand being a product or a service. Then, we also gauged parent brand attitude and familiarity as covariates.

\subsection{Results}

The manipulation check on the perception of the nature of the parent brand confirmed that this measure was only influenced by the relevant factor $\left(M H P=2.13, M_{\text {Vodafone }}=5.96\right.$, $F(1,136)=229.4, p<.01)$, not by the story type or the factor interaction $(p$ 's $>.5)$. HP and Vodafone did not differ in their similarity to the electricity provision category $\left(M_{H P}=2.06\right.$, $\left.M_{\text {Vodafone }}=2.33, F(1,136)=1.95, p>.15\right)$, and the similarity perception was not influenced by the story type factor or the factor interaction $(p$ 's $>.7)$.

The ANCOVA on brand extension evaluation found main effects of both parent brand nature $(F(1,134)=5.06, p<.05)$ and story type $(F(1,134)=3.07, p=.05)$. Their interaction did not achieve statistical significance $(F(1,134)=1.21, p=.3)$. Noting the expected pattern of results, we ran planned contrasts (cf., Iacobucci 2001) to test if the evaluations of the HP versus Vodafone electricity provider differ across conditions. The results (see Figure 5) revealed that the Vodafone electricity provider earned more favorable ratings than the HP electricity provider in the no story condition $(4.28$ vs. $3.57, F(1,134)=4.58, p<.05)$ and the product story condition $(4.17$ vs. $3.61, F(1,134)=2.93, p<.09)$, but not in the service story condition $(4.42$ vs. $4.40, F(1,134)=.003, p>.9)$. We therefore find support for H5.

(Figure 5)

A similar analysis for the perception of association relevance indicated main effects of both parent brand nature $(F(1,134)=17.12, p<.01)$ and story type $(F(1,134)=3.42, p<$ $.05)$, while the interaction did not reach statistical significance $(F(1,134)=2.23, p=.11)$. As portrayed in Figure 6, planned contrasts (cf., Iacobucci 2001) found that the associations of Vodafone are perceived as significantly more relevant than those of HP in the no story (4.54 
vs. $3.61, F(1,134)=6.53, p<.05)$ and product story $(4.54$ vs. $3.15, F(1,134)=14.46, p<.01)$ conditions, but not in the service story condition (4.66 vs. $4.36, F(1,134)=.68, p>.4)$.

(Figure 6)

Further analysis found the evaluation of the HP electricity provider varied significantly between the no story and service story conditions $(3.57$ vs. $4.40, F(2,134)=$ $6.11, p<.01)$, and so did the association relevance score $(3.61$ vs $4.36, F(2,134)=4.14, p<$ $.05)$. The difference in brand extension evaluation was fully accounted for by the perception of association relevance $\left(\beta_{\text {indirect }}=.22 ; 95 \% \mathrm{CI}\right.$. .03 to .55$)$. The evaluation of the HP electricity provider also differed between the product and service story conditions (3.61 vs. $4.40, F(2,134)=5.88, p<.01)$, as did the association relevance score $(3.15$ vs 4.36 , $F(2,134)=11.14, p<.01)$. Again, the difference in brand extension evaluation was fully explained by perceptions of association relevance $\left(\beta_{\text {indirect }}=.35 ; 95 \% \mathrm{CI}\right.$ : .09 to .81$)$.

\subsection{Discussion}

With a manipulation of process approach (Spencer et al. 2005), Study 4 provides strong evidence that associations with service benefits are what allow service brands to extend more successfully than product brands into low similarity service categories. Specifically, a product brand endowed with service associations receives just as favorable evaluations as a service brand when moving into a low similarity service category.

Conversely, a service brand maintains its edge against a product brand when the latter remains in a product domain, whether keeping to its traditional areas or having previously expanded into other product offerings. The results we obtain for brand extension evaluation as dependent measure parallel those we obtain for the association relevance measure too. In this respect, it is worthwhile noting that, while participants in Study 4 normally recognize HP as a product and Vodafone as a service brand (as per the manipulation check result above), the associations of the brand HP were updated in the service story condition compared to the 
product story and no story conditions. As evidenced by the results on association relevance, the service story condition (relative to the other two conditions) induced service provision credentials for HP, found to be relevant for an electricity provider.

Study 5 further documents the role that service-specific associations play in consumers' evaluation of service-to-service extensions. Specifically, we investigate whether restricting or making such associations less accessible leads to similarity playing a more significant role in how consumers evaluate service-to-service brand extensions. Any service brand features a collection of brand associations, including those that are relevant across multiple service domains (Brady and Cronin 2001; Parasuraman et al. 1985, 1988). Limiting the accessibility of such service associations might allow similarity to affect even more how consumers evaluate extensions of service brands into other service categories. The rationale is based on the accessibility-diagnosticity principle (Feldman and Lynch 1988; Meyvis and Janiszewski 2004), according to which a diagnostic cue informs consumer judgments to the extent it can be retrieved from memory (i.e., is accessible). Making service associations less accessible may result in such associations being less diagnostic for brand extension evaluation, in which case consumers would turn to similarity when evaluating brand extensions into a service category. Formally:

H6: The less accessible brand service associations are, the more similarity affects the evaluation of service brands extensions in a given service category.

\section{Study 5}

Information accessibility depends on (1) the degree to which the information has been elaborated upon, (2) retrieval cues, and (3) the degree of interference from other associations (Feldman and Lynch 1988; Meyvis and Janiszewski 2004). In Study 5, we presented participants with proposed logos for service-to-service brand extensions, manipulating the copy of such logos to introduce interfering associations and decrease the accessibility of 
service-specific associations. Specifically, we manipulated the presence of a product element in the logo of service-to-service extensions; we judged that portraying a product in the logo would reduce the accessibility and consequent diagnosticity of brand service-specific associations. For instance, the Easy brand stretches across service categories including the category of pizza deliveries, an extension for which the company chose to include a pizza slice (a product representing the extension category) in the logo (Appendix C). We propose that this inclusion is detrimental to the Easy Pizza offering, because it clutters the logo with product associations and prompts consumers to focus on the low similarity between the Easy brand and pizza deliveries, rather than on the brand's service associations.

\subsection{Method}

Participants saw one of two service brands, low or high on similarity to the extension category, which was cable TV services in this study. We pretested 10 service brands to identify high and low similarity options; the 33 pretest participants indicated that HSBC and Vodafone differed in their similarity to cable TV $(1.71$ vs. $4.46, t(32)=7.16, p<.01)$.

The main experiment included 102 MBA students from a U.K. university (mean age $=$ 31.23 years, $38.2 \%$ women). To clearly distinguish the parent brand and its extension into cable TV services, we named the latter "Vision." To manipulate the presence of a product element in the brand extension logo, we designed it to include a picture of a TV or not. In addition, we varied the brand name strategy reflected by the logo. The "Vision" extension was presented as either a subbrand or an endorsement by the parent brand (Aaker and Joachimsthaler 2000); according to Sood and Keller (2012), a subbrand versus endorsed brand logo may affect whether similarity influences brand extension evaluations, so we specifically included this factor. Therefore, the experiment had a $2 \times 2 \times 2$ between-subjects design, and the manipulated factors were similarity (HSBC low similarity vs. Vodafone high 
similarity), the presence of the product element (present vs. absent), and the brand name strategy (subbrand vs. endorsed brand). The corresponding logos are in Appendix D.

On the first screen in the online study, participants encountered the parent brand (HSBC or Vodafone) and information about its intention to extend into the cable TV category. On a subsequent page, the logo of the extension appeared on top (see Appendix D), and participants provided brand extension evaluations (as in Study 2). We also measured association relevance ("HSBC/Vodafone has attributes that can be relevant for cable TV"). For manipulation checks, we gauged brand extension similarity and the nature of the parent brand (product or service). We also measure parent brand attitude, parent brand familiarity, and extension category familiarity as covariates.

\subsection{Results}

The manipulation check confirmed that the similarity measure was only influenced by the manipulation of similarity $(F(1,102)=31.08, p<.01)$, not by the other two factors or the factor interactions ( $p$ 's>.09). Further analysis on the measure of parent brand nature did not find any significant influence ( $p$ 's $>.07$ ), so both HSBC and Vodafone were perceived as service brands to comparable extents, and this perception was not unduly influenced by the experimental manipulations. The subsequent ANCOVA analyses on both brand extension evaluation and association relevance reveal that the branding strategy (subbrand vs. endorsed brand) had no impact on either dependent variable $(p>.15)$, and importantly the three-way effects were not significant $(p>.3)$. Therefore, we dropped the brand strategy factor from the subsequent analyses.

The ANCOVA on brand extension evaluation indicated a main effect of similarity $(F(1,95)=7.91, p<.05)$, qualified by the significant interaction with the presence of the product element $(F(1,95)=9.37, p<.01)$. No other effects in the model were significant $(p>$ .2). Planned contrasts (as per Figure 7) suggested that the Vodafone cable TV evoked 
significantly better evaluations than the HSBC cable TV when the product element was present in the logo $(4.67$ vs. $3.38, F(1,95)=14.6, p<.01)$, but not when it was absent $(3.96$ vs. 4.04, $F(1,95)=.07, p>.7)$. These results offer support for H6.

(Figure 7)

The evaluation of the extension of HSBC into cable TV services also was significantly better when the product element was absent rather than present (4.04 vs. 3.38, $F(1,95)=4.87, p<.05)$. For the Vodafone extension, the results instead suggested that evaluations diminished when the product element was absent rather than present (3.96 vs. 4.67, $F(1,95)=4.58, p<.05)$. The parallel analysis with association relevance as the dependent variable also indicated a significant interaction effect $(F(1,95)=5.34, p<.05)$, as we show in Figure 8.

(Figure 8)

Bootstrapping tests with 5,000 subsamples confirmed that the effect of the presence versus absence of the product element had an indirect, significant effect $\left(\beta_{\text {indirect }}=.43 ; 95 \%\right.$ CI: 11 to .91) on evaluations of the low similarity extension, HSBC cable TV, via association relevance. The direct effect was insignificant $\left(\beta_{\text {direct }}=.23, p>.4\right)$, suggesting full mediation. A parallel analysis for Vodafone cable TV as the high similarity extension did not offer evidence of mediation through association relevance $\left(\beta_{\text {direct }}=.13,95 \% \mathrm{CI}:-.54\right.$ to .29$)$.

\subsection{Discussion}

Study 5 results confirm service associations play a critical role when service brands extend into other service categories. Specifically, similarity exerts a stronger effect on evaluation when service brands extend into other service categories if service associations are less accessible. For extensions of service brands into service categories, using (vs. not using) a product element in the brand extension logo leads to poorer evaluations of low similarity extensions compared with high similarity extensions. Consistent with the results of the 
previous experimental studies reported in this work, low and high similarity service-toservice extensions receive comparable evaluations if service associations are not restrained.

\section{General discussion}

We demonstrate that service-to-service brand extensions are less constrained by the similarity between the parent brand and extension category, compared with extensions involving parent brands or extension categories of a product nature. Specifically, across studies using real-life brands, we find that similarity affects brand extension evaluations significantly less when a service brand extends into services, rather than into products (Studies 1 and 3), as well as that similarity affects evaluations significantly less when service rather than product brands extend into a service category (Studies 2 and 3). These findings hold for both hypothetical (Studies 1 and 2) and real-life (Study 3) brand extensions.

To arrive at these results, we build on evidence that perceptions of brand extension fit emerge through both similarity and association relevance (Broniarczyk and Alba 1994; Monga and Gürhan-Canli 2012; Spiggle et al. 2012), and use insights from the service quality literature (Brady and Cronin 2001; Parasuraman et al. 1988) to argue that service brands possess associations that are relevant for other service categories, irrespective of how similar or dissimilar they are. Such associations lead to higher evaluations when a service brand extends into a low similarity service compared with a low similarity product category (Studies 1 and 3). These associations also account for why, given a certain service extension category, a low similarity extension by a service brand is better evaluated than a low similarity extension by a product brand (Studies 2, 3, and 4). With Study 4 we provide direct evidence of this mediation mechanism by manipulating it (Spencer et al. 2005); we demonstrate that a servitized product brand can extend as successfully as a service brand into a low similarity service category. We further document the importance of service associations 
in Study 5: restricting the accessibility of such associations for service brands allows similarity to take a stronger role in driving evaluations of service-to-service brand extensions.

In Study 1 we also obtained a result that, though not contradictory to our theoretical reasoning, was somewhat less expected. We suggest that such a result likely reflects our choice of experimental stimuli. In Study 1, our measure of association relevance appears to indirectly explain the higher evaluation score for the high similarity service-to-product extension (Vodafone car GPS device) relative to the high similarity service-to-service extension (Vodafone online music streaming). In retrospect, both online music streaming and car GPS devices may evoke strong similarity with Vodafone, but Vodafone's associations might appear especially relevant for the latter, considering how frequently consumers use their mobile phones as GPS devices. Evidence suggesting that this Study 1 finding is idiosyncratic also comes from further analysis of Study 3 data: for high similarity extensions ( similarity score $=5.57,84 \%$ percentile) and when the parent brand nature is service rather than product (brand nature score $=6.00,84 \%$ percentile), the impact of extending to a service rather than a product category on brand extension evaluation is non-significant $\left(\beta_{\text {nature_EC }}=\right.$ $-.06, p>.5)$. In these data, association relevance does not act as mediator for an indirect effect either $\left(\beta_{\text {indirect }}=-.02 ; 95 \% \mathrm{CI}:-.11\right.$ to .06$)$.

Similarly, we would not expect high similarity extensions to the same service category to receive significantly different evaluations depending on parent brand nature. For instance, in Study 2, the evaluations of Pfizer and Aviva online medical services are not significantly different. Further analysis of Study 3 data also suggests that, at high levels of similarity ( similarity score $=5.57,84 \%$ percentile) and when the extension category is of a service nature, the effect of the parent brand nature being service rather than product is nonsignificant $\left(\beta_{\text {nature } P B}=-.01, \mathrm{p}>.5\right)$. One might reason that high similarity service-to-service extensions benefit from both high similarity and association relevance (i.e., the latter given 
service-specific associations), and could thus fare better than high similarity service-toproduct or product-to-service extensions (i.e., which just benefit from a high similarity). However, current research (Monga and Houston 2002; Spiggle et al. 2012) suggests that both similarity and association relevance represent brand extension fit, and can independently trigger high evaluations. Therefore, in this work we refrain from hypothesizing significant differences in evaluation between high similarity service-to-service and respectively serviceto-product or product-to-service extensions, as we lack a theoretical rationale to do so.

Our work contributes to literature by documenting that the mechanisms of brand extension evaluation differ for service brands, especially if such brands extend to new services. Although prior brand extension research highlights the crucial role of fit (Aaker and Keller 1990; Völckner and Sattler 2006), we demonstrate that fit understood as similarity is less of a constraint for service-to-service extensions than for extensions involving product dimensions. In parallel, we add to the evidence documenting that dissimilar brand extensions can also be perceived to fit if the parent brand associations deliver benefits relevant to the extension category (e.g., Broniarczyk and Alba 1994; Spiggle et al. 2012). Our work is the first to demonstrate that this principle applies to the important context of service brands stretching to dissimilar service offerings, given such brands possess associations relevant across the service spectrum.

Considering such findings, a pertinent question is whether product-to-product extensions might also benefit from associations relevant across the product spectrum. Data analysis presented in Study 3 disapproves such a possibility. Also, current research does not offer any evidence regarding universal benefits that might transcend the content of product operations, and which are uniquely applicable to products. Aaker and Keller (1990) introduce the idea of transferability of production (i.e., manufacturing) skills as an important influencer of brand extension evaluation. They find that transferability significantly affects evaluations 
of product-to-product extensions, as not all products entail the same type of manufacturing skills and processes. In a similar fashion, it is not easy to conceive of technology, design, fabrication processes, logistic capabilities, or materials and components that are universally applicable to all manufacturing processes. Where associations are applicable across different product offerings, e.g., Apple's associations of being "easy-to-use", "cool” or "exclusive", such associations tend to be symbolic or image-based rather than functional or physical (cf., Carter and Curry 2013; Park et al. 1991), and thus equally applicable to service and product domains.

At a general level, we contribute to the academic debate documenting differences in the principles for managing service vs. product brands. To exemplify, service brands entail a heightened focus on managing brand reputation, rather than concrete attributes (Berry 2000); they require ensuring a consistent brand experience across service encounters, as well as forging close relationships between employees and the brand (Ostrom et al. 2010); and, differently from service brands, they require specific strategies for brand growth focusing on service quality, personalization and relationships (Huang and Dev 2020). We add to such evidence by demonstrating that, whereas the principle of extending to similar categories holds strong in a product brand extension context (Boush and Loken 1991; Park et al. 1991; Völckner and Sattler 2007), it applies to a lesser extent to the context of service brands extending to service categories; in the latter case, the degree of similarity becomes less of limitation given that service brands are endowed with associations applicable to distinct service offerings.

Through Study 4, our paper also contributes to the body of work on servitization, defined as 'the addition of services to manufacturers' core product offerings to create additional customer value" (Raddats et al. 2019, p. 207). While a wealth of servitization research focuses on operations and supply chains aspects (c.f., Ostrom et al. 2015), this work 
sheds light on how consumers might react to product brands' servitization efforts.

Specifically, we show that product brands that build service dimensions to their offerings can have the consumer buy-in to expand their offering further, to remote service domains.

\subsection{Managerial implications}

Several results of the current investigation suggest meaningful recommendations for managers, of both service brands and product brands. As the real-life examples of brands such as Virgin, Easy, or the Co-operative also indicate, managers of service brands have the latitude to expand their brands into both similar and dissimilar service domains. However, extensions to low similarity product categories should generally be avoided, as service associations cannot be leveraged in product domains. To increase the success of extensions to low similarity service categories, managers of service brands also should eliminate any factors that might constrain the accessibility of service associations. For example, even the inclusion of a product element in extension's logo can impede the accessibility of service associations to consumers evaluating a service-to-service brand extension. As a general recommendation, for low similarity service-to-service extensions, brand managers should avoid marketing communication that touts product aspects of the new offering.

Managers of product brands instead need explicitly to seek out extensions into similar categories (i.e., of either product or service nature). Still, the current evidence suggests that even product brands can be servitized and imbued with service associations that will help them extend to dissimilar service categories. In this work we servitized a product brand by citing fictional press coverage according to which the brand started a service offering; as we show in Study 4, communicating about credible, value-added services offered by a product brand can build that brand's service credentials. Thus, our results suggest that, by adding service components to their offerings, product brands are able to launch further dissimilar service extensions. The relevance of our findings is heightened given the current trend of 
accelerated servitization during Covid-19: faced with such a global crisis, many manufactures found a new impetus to adapt their business models by embracing services, not least supported by technology and digital platforms (Rapaccini et al. 2020, Tian et al. 2021). Servitization has been shown to increase business resilience against crises (Rapaccini et al. 2020), and our own results suggest a positive consumer reaction to servitizing product brands.

\subsection{Limitations and future research}

In this work, we presented evidence that service-to-service, but not product-to-product brand extensions, benefit from domain-specific associations. For instance, we find that similarity has a smaller effect on the evaluation of service-to-service extensions compared to extensions spanning domains (i.e., service-to-product or product-to-service). Study 3 data suggest that the same principle does not apply to product-to-product extensions. In addition, Study 3 data show that low similarity service-to-service, but not low similarity product-toproduct extensions, fare better than low similarity extensions that span domains. However, a further experimental study could directly compare between product-to-product and serviceto-service brand extensions. To ensure a degree of experimental control, in our Study 1 we kept the service brand constant (i.e., Vodafone), manipulating the extension category nature and the degree of similarity. In our Study 2 we kept the service extension category constant (i.e., online medical services), manipulating the parent brand nature and the degree of similarity. To directly compare service-to-service and product-to-product extensions, future research can however conduct a carefully calibrated $2 \times 2 \times 2$ experiment, simultaneously manipulating parent brand nature, extension category nature and the degree of similarity.

As stimuli in our experiments, we made the choice to use real-life instead of fictional brands. While constructing fictional brands might have further aided experimental control, we judged that the ability to leverage transcending service associations is a latitude of brands 
with an established reputation for delivering quality. Employing fictional brands and instilling perceptions of their performance on different service dimensions could have proved unwieldy and failed to serve our research purposes. In our work, the parent brand was actually kept the same for all conditions in Study 1 (Vodafone) and for comparing extensions by the same brand in Studies 4 and 5. When we compared extensions by different brands (Studies 2, 4 and 5), we also performed extensive pretesting to ensure the brands included as experimental stimuli are well-matched on the manipulated dimensions. The successful tests of our theory across four experiments and one survey give us confidence that the results are robust, and not just a consequence of the choice of particular experimental stimuli. However, we still acknowledge this purposeful design aspect as a potential limitation.

To establish that service-specific associations allow service brands to extend to even dissimilar service categories, we both measured (Studies 1-5), and manipulated the presence of these associations (Study 4) or alternatively their accessibility (Study 5). Yet the purpose of our study was not to measure or manipulate particular service attributes or credentials. It would however be helpful to zoom in on the specific nature of service associations, whether through measurement or manipulation. For instance, future work could manipulate a brand's association with a physical environment of service delivery, and explore whether extensions into categories where such attribute is necessary (e.g., cafés) are likely successful when originating from brands with a physical presence (e.g., the fashion retailer Zara) rather than from brands with a fully online presence (e.g., the online fashion retailer Asos).

In our empirical results in Studies 1 and 5, several evaluation scores ranged around the middle of the scale (i.e., 4.00) (Vodafone bank in Study 1, HSBC cable TV in Study 5). Such results do not contradict our hypotheses; however if evaluation scores are indicative of possible market acceptance, Lane (2000) and Klink and Smith (2001) suggest that repeated exposures to a brand extension concept can significantly improve evaluations of the 
extension. For example, in Lane's (2000) study, Michelin's extension into sports sandals received middling scores after one exposure, but high scores after five exposures (however, repeated exposures did not aid extensions with initially poor evaluations). To replicate such results and elevate evaluation scores, further experimental studies might be conducted along similar lines, using brand extensions of a service-to-service nature.

As our general thesis, we predict that extensions of service brands into service categories are less constrained by similarity, so service brands can extend into other, low similarity services. In addition to a reduction in the accessibility of service associations, other factors also might qualify this assertion. For example, the low similarity extension by the hair salon brand Toni \& Guy into electricity provision is likely to evoke poor evaluations, but not necessarily as a consequence of a failure to apply service associations to the extension category. Rather, Toni \& Guy possesses idiosyncratic associations (beyond service associations) that may appear negative or detrimental in the context of the extension category (cf., Aaker and Keller 1990). Additional studies might consider other such boundary conditions to our theory.

Our research could be extended in yet other valuable ways. As with most brand extension research to date (e.g., Aaker and Keller 1990; Mathur et al. 2012; Parker et al. 2018), we looked at consumers' evaluations of B2C brand extensions. Nevertheless, recent research demonstrates that, just like in $\mathrm{B} 2 \mathrm{C}$ markets, brand extensions also drive profitability significantly in B2B markets (Liu et al. 2018). Other scholars point out that B2B service firms can use branding strategically to fight commoditization and create competitive advantage, and thus shareholder value (Guenther and Guenther 2019). Therefore, fruitful future research could investigate if, like in B2C contexts investigated here, industrial customers have a parallel appreciation of transcending service brand associations and thus B2B service brands are not constrained in extending to other service offerings. 


\section{References}

Aaker, David A. and Erich Joachimsthaler (2000), "The Brand Relationship Spectrum: The Key to the Brand Architecture Challenge," California Management Review, 42(4), 8-23.

Aaker, David A. and Kevin Lane Keller (1990), "Consumer Evaluations of Brand Extensions," Journal of Marketing, 54 (1), 27-41.

Aksoy, Lerzan, Alexander Buoye, Bruce Cooil, Timothy L. Keiningham, DeDe Paul, and Chris Volinsky (2011), "Can We Talk? The Impact of Willingness to Recommend on a New-toMarket Service Brand Extension within a Social Network," Journal of Service Research, 14 (3), 355-71.

Barone, Michael J. (2005), "The Interactive Effects of Mood and Involvement on Brand Extension Evaluations," Journal of Consumer Psychology, 15 (3): 263-70.

Berry, Leonard L. (2000), “Cultivating Service Brand Equity,” Journal of the Academy of Marketing Science, 28 (1), $12-137$.

Boisvert, Jean (2012), “The Impact of Vertical Service Line Extensions and Brand Salience on Reciprocal Transfer of Image and Performance Associations," Journal of Service Research, 15 (4), 443-59.

Boush, David M. and Barbara Loken (1991), “A Process-Tracing Study of Brand Extension Evaluation," Journal of Marketing Research, 28 (1), 16-28.

Brady, Michael K. and Joseph Cronin Jr. (2001), "Some New Thoughts on Conceptualizing Perceived Service Quality: A Hierarchical Approach,” Journal of Marketing, 65(3), 34-49.

Brand Finance (2017), "US 5002016 The most valuable US brands of 2016," (accessed May 2, 2017), http://brandirectory.com/league_tables/table/us-500-2016.

Broniarczyk, Susan M. and Joseph W. Alba (1994), "The Importance of the Brand in Brand Extension," Journal of Marketing Research, 31(2), 214-228.

Business Insider (2012), "Richard Branson's Fails: 14 Virgin Companies that Went Bust,” (accessed May 13, 2020), http://www.businessinsider.com/richard-branson-fails-virgin-companies-thatwent-bust-2012-4?IR=T.

Carter, Robert, and David Curry (2013), "Perceptions versus Performance When Managing Extensions: New Evidence about the Role of Fit between a Parent Brand and an Extension," Journal of the Academy of Marketing Science, 41 (2), 253-69.

Cutright, Keisha M., James R. Bettman, and Gavan J. Fitzsimons (2013), "Putting Brands in Their Place: How a Lack of Control Keeps Brands Contained," Journal of Marketing Research, 50 (3), 365-77. 
Dacin, Peter A. and Daniel C. Smith (1994), "The Effect of Brand Portfolio Characteristics on Consumer Evaluations of Brand Extensions," Journal of Marketing Research, 31(2), 229242.

Dimitriu, Radu, Luk Warlop, and Bendik Meling Samuelsen (2017), "Brand Extension Similarity Can Backfire When You Look for Something Specific," European Journal of Marketing, 51(5/6), $850-868$.

de Ruyter, Ko and Martin Wetzels (2000), "The role of corporate image and extension similarity in service brand extensions," Journal of Economic Psychology, 21(6), 639-659.

Feldman, Jack M. and John G. Lynch Jr. (1988), "Self-Generated Validity and Other Effects of Measurement on Belief, Attitude, Intention and Behavior," Journal of Applied Psychology, 73(3), 421-435.

Guenther, Miriam, and Peter Guenther (2019). "The Value of Branding for B2B Service Firms-The Shareholders' Perspective," Industrial Marketing Management, 78, 88-101.

Hansen, Jochim, Florian Kutzner, and Michaela Wänke (2013), "Money and Thinking: Reminders of Money Trigger Abstract Construal and Shape Consumer Judgments," Journal of Consumer Research, 39(6), 1154-1166.

Hayes, Andrew F. (2017), Introduction to Mediation, Moderation, and Conditional Process Analysis: A Regression-Based Approach. New York, NY, Guildford Press ( $2^{\text {nd }}$ ed.).

Hayes, Andrew F. and Kristopher J. Preacher (2010), "Quantifying and Testing Indirect Effects in Simple Mediation Models When the Constituent Paths Are Nonlinear," Multivariate Behavioral Research, 45(4), 627-660.

Hem, Leif E., Leslie de Chernatony, and Nina M. Iversen (2003), "Factors Influencing Successful Brand Extensions, " Journal of Marketing Management, 19(7-8), 781-806.

Huang, Ming-Hui and Chekitan S. Dev (2020), "Growing the Service Brand," International Journal of Research in Marketing, 37(2), 281-300.

Iacobucci, Dawn (2001), “Analysis of Variance,” Journal of Consumer Psychology, 10(1\&2), 5-35.

Iacobucci, Dawn and Amy Ostrom (1996), "Perceptions of Services," Journal of Retailing and Consumer Services, 3(3), 1-18.

Keller, Kevin Lane (2008), Strategic brand management: building, measuring, and managing brand equity. Upper Saddle River, NJ, Pearson Education.

Kim, Kyeongheui and Jongwon Park (2019), "Cultural Influences on Brand Extension Judgments: Opposing Effects of Thinking Style and Regulatory Focus," International Journal of Research in Marketing, 36 (1), 137-50. 
Klink, Richard R. and Daniel C. Smith (2001), "Threats to the External Validity of Brand Extension Research," Journal of Marketing Research, 38(3), 326-335.

Lane, Vicki R. (2000), “The Impact of Ad Repetition and Ad Content on Consumer Perceptions of Incongruent Extensions," Journal of Marketing, 64(2), 80-91.

Lehmann, Donald R., Jennifer Ames Stuart, Gita Venkataramani Johar, and Anil Thozhur (2007), "Spontaneous visualization and concept evaluation," Journal of the Academy of Marketing Science, 35(3), 309-316.

Lei, Jing, Ko de Ruyter, and Martin Wetzels (2008), "Consumer Responses to Vertical Service Line Extensions," Journal of Retailing, 84(3), 268-280.

Lei, Jing, Roger Pruppers, Hans Ouwersloot, and Jos Lemmink (2004), "Service Intensiveness and Brand Extension Evaluations," Journal of Service Research, 6(3), 243-255.

Liu, Yeyi, Thomas Foscht, Andreas B. Eisingerich and Huei-Ting Tsai (2018), "Strategic management of product and brand extensions: Extending corporate brands in B2B vs. B2C markets," Industrial Marketing Management, 77, 147-159.

Loken, Barbara and James Ward (1987), "Measures of the Attribute Structure Underlying Product Typicality," Advances in Consumer Research, 14 (1), 22-26.

Loken, Barbara, and James Ward (1990), “Alternative Approaches to Understanding the Determinants of Typicality," Journal of Consumer Research, 17 (2), 111-26.

Mao, Huifang and H. Shanker Krishnan (2006), "Effects of Prototype and Exemplar Fit on Brand Extension Evaluations: A Two-Process Contingency Model," Journal of Consumer Research, $33(1), 41-49$.

Martínez, Eva and José M. Pina. 2005 (2005), "Influence of Corporate Image on Brand Extensions: A Model Applied to the Service Sector," Journal of Marketing Communications, 11(4), 263281.

Mathur, Pragya, Shailendra P. Jain, and Durairaj Maheswaran (2012), “Consumers' implicit theories about personality influence their brand personality judgments," Journal of Consumer Psychology, 22(4), 545-557.

Meyvis, Tom, Kelly Goldsmith, and Ravi Dhar (2012), "The Importance of the Context in Brand Extension: How Pictures and Comparisons Shift Consumers' Focus from Fit to Quality,” Journal of Marketing Research, 49(2), 206-217.

Meyvis, Tom and Chris Janiszewski (2004), “When Are Broader Brands Stronger Brands? An Accessibility Perspective on the Success of Brand Extensions, " Journal of Consumer Research, 31(2), 346-357. 
Miniard, Paul W., Rama K. Jayanti, Cecilia M. O. Alvarez, and Peter R. Dickson (2018), "What brand extensions need to fully benefit from their parental heritage," Journal of the Academy of Marketing Science, 46(5), 948-963.

Monga, Alokparna Basu and Zeynep Gürhan-Canli (2012), “The Influence of Mating Mind-Sets on Brand Extension Evaluation," Journal of Marketing Research, 49(4), 581-593.

Monga, Alokparna Basu and Deborah Roedder John (2010), "What Makes Brands Elastic? The Influence of Brand Concept and Styles of Thinking on Brand Extension Evaluation,” Journal of Marketing, 74(3), 80-92.

Monga, Ashwani and Michael J. Houston (2002), "The Brand Extension Evaluation Process: Insights from the Continuum Model of Impression Formation," Advances in Consumer Research, 29(1), 188-189.

Ostrom, Amy L., Mary Jo Bitner, Stephen W. Brown, Kevin A. Burkhard, Michael Goul, Vicki Smith-Daniels, Haluk Demirkan, and Elliot Rabinovich (2010), "Moving Forward and Making a Difference: Research Priorities for the Science of Service," Journal of Service Research, 13(1), 4-36.

Ostrom, Amy L., A. Parasuraman, David E. Bowen, Lia Patrício, and Christopher A. Voss (2015), "Service Research Priorities in a Rapidly Changing Context," Journal of Service Research, 18 (2), 127-159.

Parasuraman, A., Valarie A. Zeithaml, and Leonard L. Berry (1985), “A Conceptual Model of Service Quality and Its Implications for Future Research,” Journal of Marketing, 49(4), 41-50.

Parasuraman, A., Valarie A. Zeithaml, and Leonard L. Berry (1988), "SERVQUAL: A Multiple-Item Scale for Measuring Consumer Perceptions of Service Quality," Journal of Retailing, 64(1), $12-40$.

Park, C. Whan, Sandra Milberg, and Robert Lawson (1991), "Evaluation of Brand Extensions: The Role of Product Feature Similarity and Brand Concept Consistency," Journal of Consumer Research, 18(2), 185-193.

Parker, Jeffrey R., Donald R. Lehmann, Kevin Lane Keller, and Martin G. Schleicher (2018), "Building a multi-category brand: when should distant brand extensions be introduced?" Journal of the Academy of Marketing Science, 46(2), 300-316.

Pina, José M., Francesca Dall’Olmo Riley, and Wendy Lomax (2013), “Generalizing spillover effects of goods and service brand extensions: A meta-analysis approach," Journal of Business Research, 66(9), 1411-1419. 
Pina, Jose M., Eva Martinez, Leslie De Chernatony, and Susan Drury (2006), “The effect of service brand extensions on corporate image," European Journal of Marketing, 40(1/2), 174-197.

Raddats, Chris, Christian Kowalkowski, Ornella Benedettini, Jamie Burton, and Heiko Gebauer (2019), "Servitization: A Contemporary Thematic Review of Four Major Research Streams," Industrial Marketing Management, 83, 207-223.

Rapaccini, Mario, Nicola Saccani, Christian Kowalkowski, Marco Paiola, and Federico Adrodegari (2020), "Navigating Disruptive Crises through Service-Led Growth: The Impact of COVID19 on Italian Manufacturing Firms," Industrial Marketing Management, 88, 225-37.

Rosch, Eleanor, and Carolyn B. Mervis (1975), "Family Resemblances: Studies in the Internal Structure of Categories," Cognitive Psychology, 7 (4), 573-605.

Sichtmann, Christina and Adamantios Diamantopoulos (2013), “The impact of perceived brand globalness, brand origin image, and brand origin-extension fit on brand extension success," Journal of the Academy of Marketing Science, 41(5), 567-585.

Sichtmann, Christina, Klaus Schoefer, Markus Blut, and Charles Jurgen Kemp (2017), "Extending service brands into products versus services: Multilevel analyses of key success drivers," European Journal of Marketing, 51(1), 200-218.

Sood, Sanjay and Kevin Lane Keller (2012), "The Effects of Brand Name Structure on Brand Extension Evaluations and Parent Brand Dilution," Journal of Marketing Research, 49(3), 373-382.

Spiggle, Susan, Hang T. Nguyen, and Mary Caravella (2012), "More Than Fit: Brand Extension Authenticity," Journal of Marketing Research, 49(6), 967-983.

Spencer, Steven J., Mark P. Zanna, and Geoffrey T. Fong (2005), "Establishing a Causal Chain: Why Experiments Are Often More Effective Than Mediational Analyses in Examining Psychological Processes," Journal of Personality \& Social Psychology, 89(6), 845-851.

Taylor, Valerie A. and William O. Bearden (2002), "The Effects of Price on Brand Extension Evaluations: The Moderating Role of Extension Similarity," Journal of the Academy of Marketing Science, 30(2), 131-140.

Tian, Jiamian, Wim Coreynen, Paul Matthyssens and Lei Shen (2021)," Platform-based servitization and business model adaptation by established manufacturers", Technovation, in press.

Torelli, Carlos J. and Rohini Ahluwalia (2012), "Extending Culturally Symbolic Brands: A Blessing or a Curse?" Journal of Consumer Research, 38(5), 933-947.

Tversky, Amos (1977), “Features of Similarity,” Psychological Review, 84, 327-52. 
van Riel, Allard C. R., Jos Lemmink, and Hans Ouwersloot (2001), "Consumer Evaluations of Service Brand Extensions," Journal of Service Research, 3(3), 220.

van Riel, Allard C. R. and Hans Ouwersloot (2005), "Extending electronic portals with new services: exploring the usefulness of brand extension models," Journal of Retailing \& Consumer Services, 12(4), 245-254.

Völckner, Franziska and Henrik Sattler (2006), “Drivers of Brand Extension Success,” Journal of Marketing, 70(2), 18-34.

Völckner, Franziska and Henrik Sattler (2007), “Empirical generalizability of consumer evaluations of brand extensions," International Journal of Research in Marketing, 24(2), 149-162.

Völckner, Franziska, Henrik Sattler, Thorsten Hennig-Thurau, and Christian M. Ringle (2010), "The Role of Parent Brand Quality for Service Brand Extension Success," Journal of Service Research, 13(4), 379-396.

World Bank (2020), "Services, value added (\% of GDP)", (accessed 5 August, 2021), https://data.worldbank.org/indicator/NV.SRV.TOTL.ZS?end=2020\&start=2020\&view=map.

Yeo, Junsang and Jongwon Park (2006), "Effects of Parent-Extension Similarity and Self Regulatory Focus on Evaluations of Brand Extensions," Journal of Consumer Psychology, 16(3), 272282.

Zeithaml, Valarie A., Leonard L. Berry, and A. Parasuraman (1996), "The Behavioral Consequences of Service Quality," Journal of Marketing, 60(2), 31-46.

Zhao, Xinshu, John G. Lynch Jr., and Qimei Chen (2010), "Reconsidering Baron and Kenny: Myths and Truths about Mediation Analysis," Journal of Consumer Research, 37(2), 197-206. 
Table 1. Brand extensions rated in Study 3

\begin{tabular}{lc}
\hline Brand Extension & $\begin{array}{c}\text { Number of } \\
\text { Respondents }\end{array}$ \\
\hline Amazon_Intelligent Personal Assistant (Alexa) & 41 \\
\hline Amazon_Online music streaming (Amazon music) & 41 \\
\hline Amazon_Smart speaker (Amazon Echo) & 38 \\
\hline Apple_Intelligent Personal Assistant (Apple Siri) & 40 \\
\hline Apple_Smart watch (Apple watch) & 40 \\
\hline Black\&Decker_Coffee machine & 40 \\
\hline Budweiser_Mini fridge & 36 \\
\hline Chevrolet_Watches & 37 \\
\hline Coca-Cola_Lip smacker & 35 \\
\hline Disney_Credit card & 38 \\
\hline Disney_Radio network (Radio Disney) & 37 \\
\hline Doritos_Dipping sauce & 34 \\
\hline DrPepper_Roller skates & 38 \\
\hline Ebay_Online ticket exchange (StubHub) & 39 \\
\hline Family Dollar_Bill payments (PayNearMe) & 34 \\
\hline Fanta_Lip smacker & 33 \\
\hline Google_Digital courses (Google digital garage) & 38 \\
\hline Google_Media streaming device (Chromecast) & 40 \\
\hline Google_Smart glasses (Google Glass) & 39 \\
\hline
\end{tabular}

\begin{tabular}{lc}
\hline Brand Extension & $\begin{array}{c}\text { Number of } \\
\text { Respondents }\end{array}$ \\
\hline Hilton_Banquet hall & 35 \\
\hline Hilton_Earphones & 39 \\
\hline Hilton_ USB stick & 39 \\
\hline Jack Daniel's_Chocolate & 33 \\
\hline Johnson's baby_Parenting advice & 37 \\
\hline Levi's_Eyewear & 32 \\
\hline Mars_Milk & 34 \\
\hline Mars_Protein bar (Mars protein) & 35 \\
\hline Mattel_Film studio & 38 \\
\hline Microsoft_Tablet computer (Microsoft surface) & 38 \\
\hline MTN Dew_Online Magazine & 39 \\
\hline MTV_T-shirt & 39 \\
\hline Nike_Personal coaching app (Nike+) & 38 \\
\hline Ralph Lauren_Bar (The Polo Bar) & 38 \\
\hline 7up_Marinades\&sauces & 37 \\
\hline Starbucks_Wireless charger & 38 \\
\hline Toys'R'Us_baby food & 38 \\
\hline Tyson foods_Renewable energy & 40 \\
\hline Uber_Food delivery (Uber Eats) & 38 \\
\hline & \\
\hline
\end{tabular}

Table 2. Variable correlation matrix (Study 3)

\begin{tabular}{|c|c|c|c|c|c|c|c|c|c|c|}
\hline & 1 & 2 & 3 & 4 & 5 & 6 & 7 & 8 & 9 & 10 \\
\hline \multicolumn{11}{|l|}{ 1. Brand extension evaluation } \\
\hline 2. Association relevance & $.776^{\star *}$ & & & & & & & & & \\
\hline 3. Association relevance as service credentials & $.592^{* *}$ & $.664^{* *}$ & & & & & & & & \\
\hline 4. Similarity & $.588^{* *}$ & $.683^{* *}$ & $.630^{* *}$ & & & & & & & \\
\hline 5. Nature parent brand (product vs. service) & $.178^{* *}$ & $.171^{* *}$ & $.343^{* *}$ & $.220^{* *}$ & & & & & & \\
\hline 6. Nature extension category (product vs. service) & $.239^{* *}$ & $.225^{* *}$ & $.210^{* *}$ & $.182^{* *}$ & $.206^{* *}$ & & & & & \\
\hline 7. Parent brand attitude & $.553^{* *}$ & $.494^{* *}$ & $.378^{* *}$ & $.321^{* *}$ & $.180^{* *}$ & $.079^{* *}$ & & & & \\
\hline 8. Parent brand familiarity & $.233^{* *}$ & $.261^{* *}$ & $.167^{* *}$ & $.117^{\star *}$ & .051 & .032 & $.361^{* *}$ & & & \\
\hline 9. Extension category attitude & $.293^{* *}$ & $.240^{* *}$ & $.159^{* *}$ & $.165^{* *}$ & $.115^{* *}$ & -.015 & $.304^{* *}$ & $.205^{* *}$ & & \\
\hline 10. Extension category familiarity & $.238^{* *}$ & $.173^{* *}$ & $.129^{* *}$ & $.131^{\star *}$ & $.095^{* *}$ & .034 & $.217^{\star *}$ & $.244^{* *}$ & $.528^{* *}$ & \\
\hline 11. Extension category personal relevance & $.308^{* *}$ & $.242^{* *}$ & $.203^{* *}$ & $.207^{* *}$ & $.148^{* *}$ & $.110^{* *}$ & $.276^{* *}$ & $.161^{* *}$ & $.640^{* *}$ & $.716^{* *}$ \\
\hline
\end{tabular}




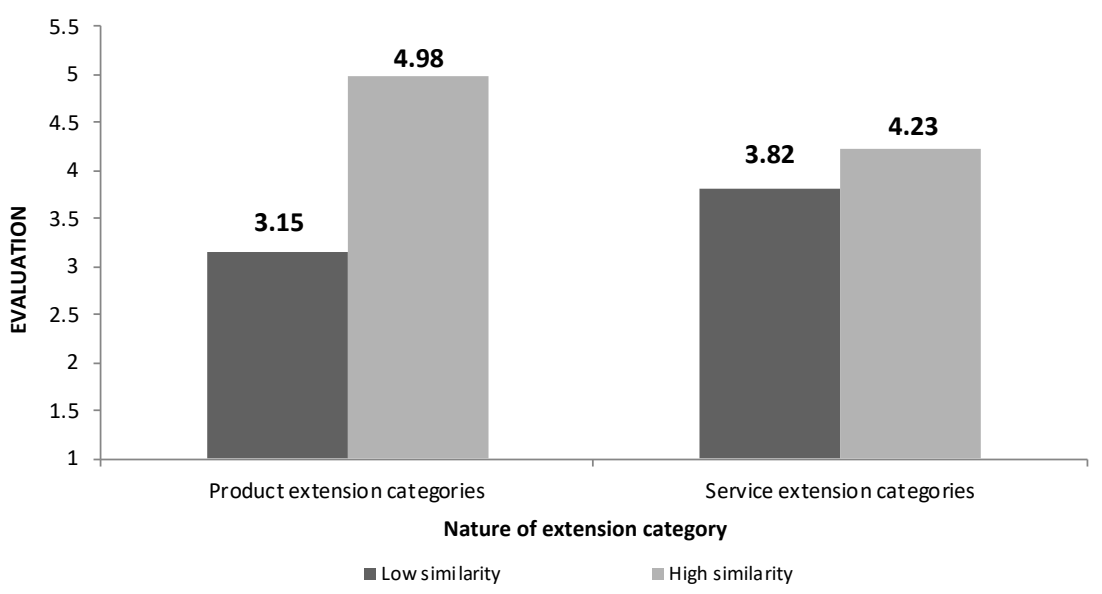

Fig. 1. Brand extension evaluation (Study 1)

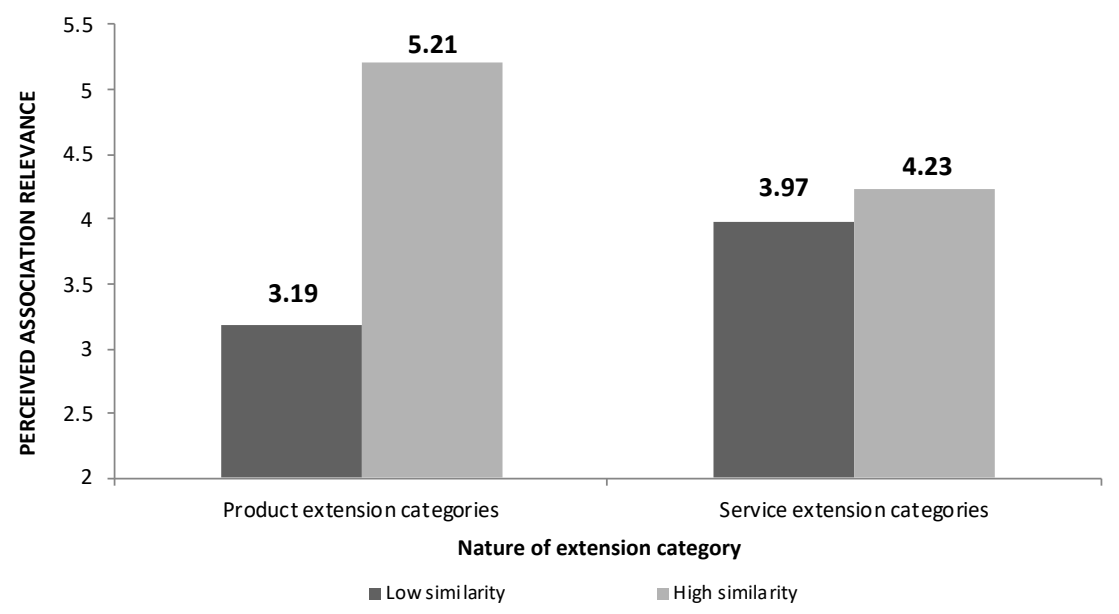

Fig. 2. Perceived parent brand association relevance (Study 1)

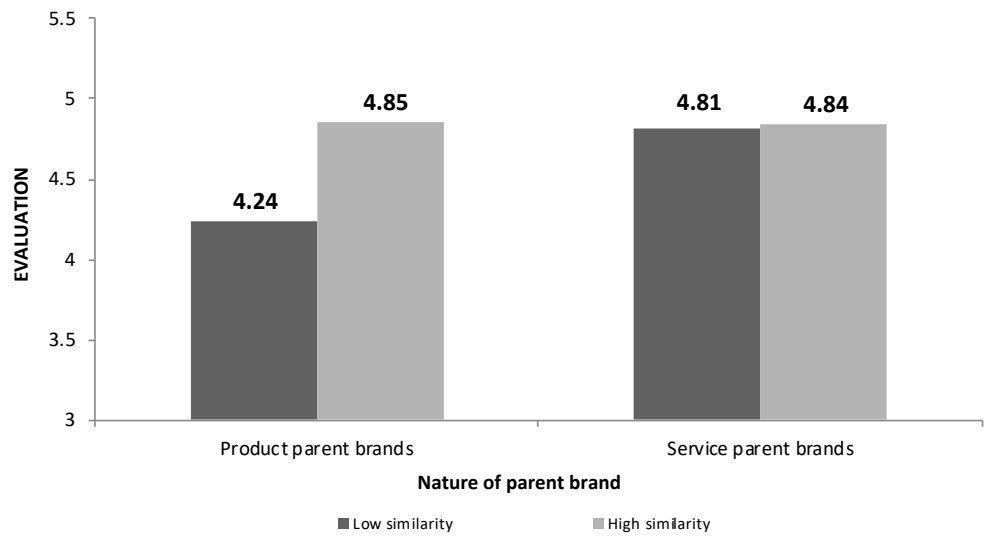

Fig. 3. Brand extension evaluation (Study 2) 


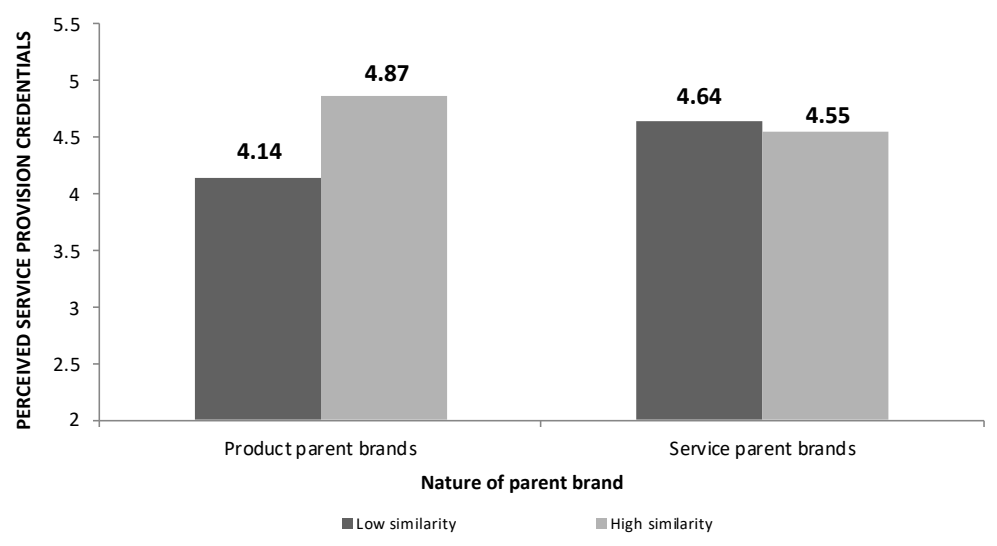

Fig. 4. Perceived parent brand association relevance as service provision credentials (Study 2)

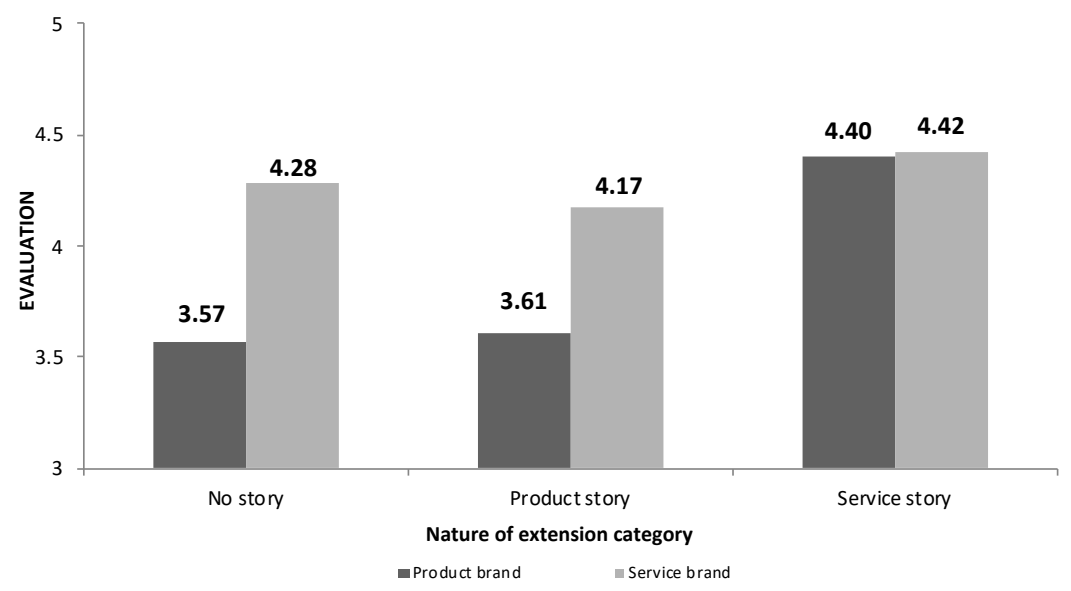

Fig. 5. Brand extension evaluation (Study 4)

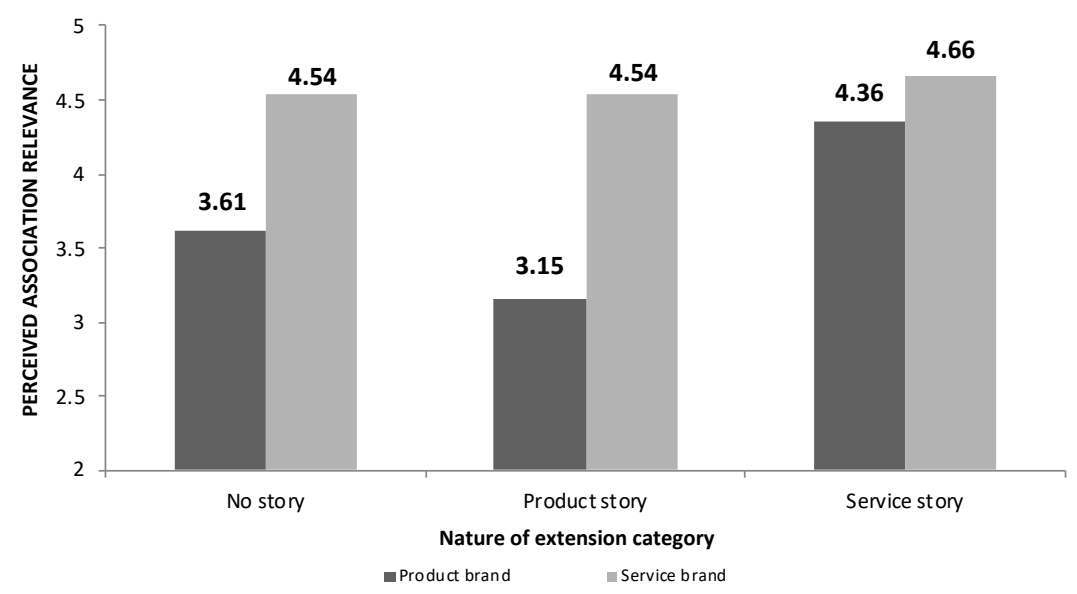

Fig. 6. Perceived parent brand association relevance (Study 4) 


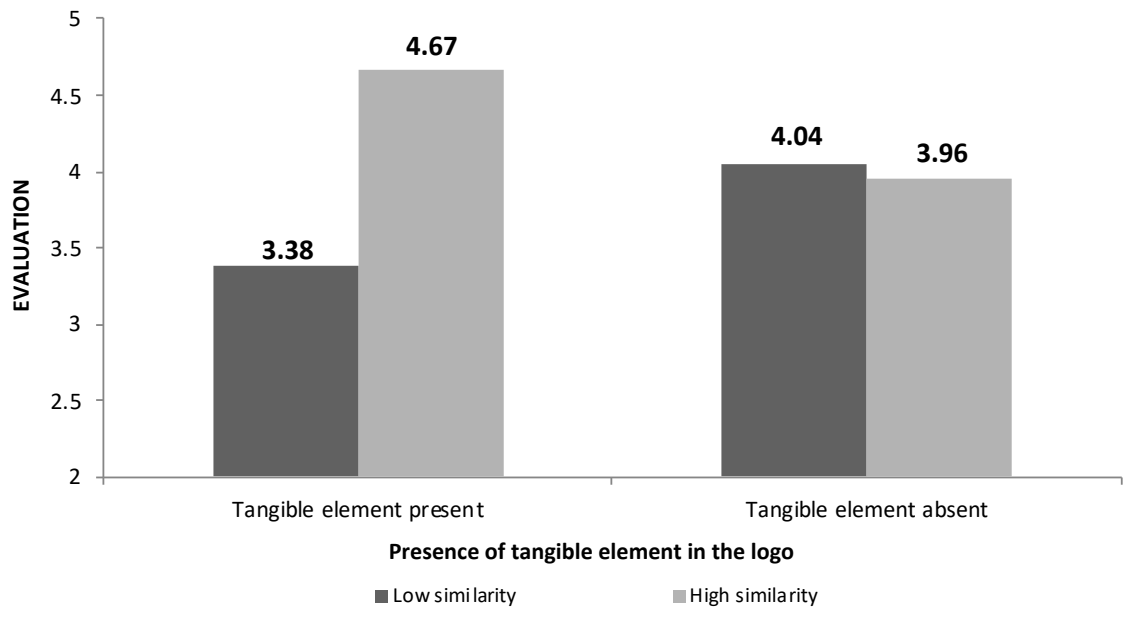

Fig. 7. Brand extension evaluation (Study 5)

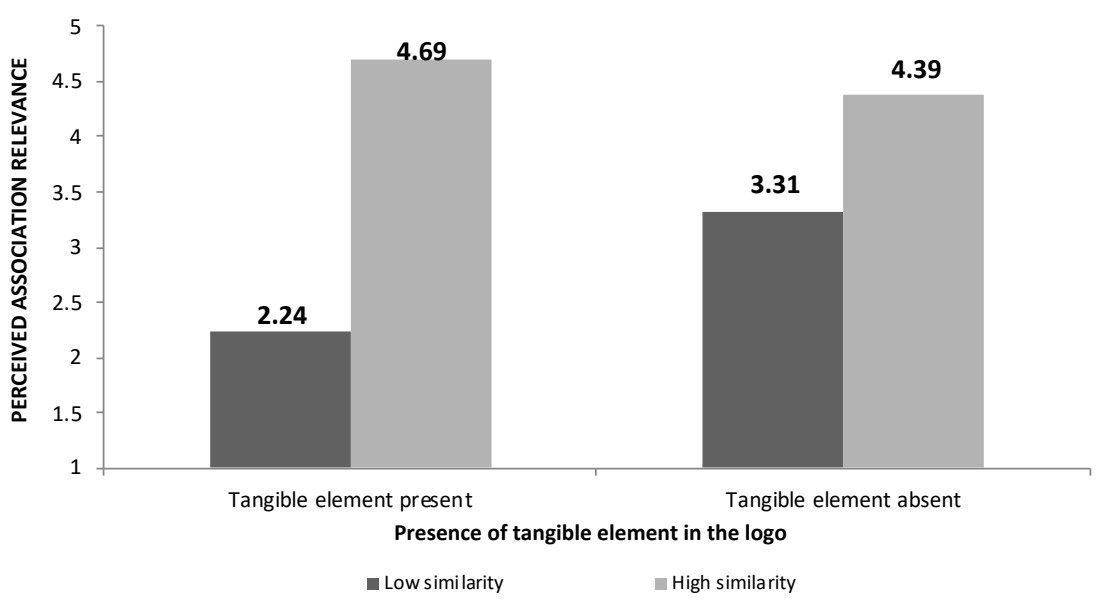

Fig. 8. Perceived parent brand association relevance (Study 5) 
Appendix $A$ - Review of academic work involving service brand extensions

\begin{tabular}{|c|c|c|}
\hline Study & Research Focus & Key Findings \\
\hline de Ruyter and Wetzels (2000) & $\begin{array}{l}\text { Examine the role of corporate image in extending service brands } \\
\text { to related vs. unrelated markets, given service brand extension } \\
\text { order of entry (pioneer vs. follower). } \\
\text { S2S brand extensions only. }\end{array}$ & $\begin{array}{l}\text { Consumers evaluate innovative late mover service extensions better } \\
\text { than pioneer service extensions; they evaluate extensions to related } \\
\text { markets better than extensions to unrelated markets. } \\
\text { The evaluation difference between late mover and pioneer service } \\
\text { extensions is greater for extensions to related (vs. unrelated) markets. }\end{array}$ \\
\hline $\begin{array}{l}\text { van Riel, Lemmink, and } \\
\text { Ouwersloot (2001) }\end{array}$ & $\begin{array}{l}\text { Replicate Aaker and Keller's (1990) findings on the role of fit } \\
\text { (complementarity, substitutability, transferability), parent brand } \\
\text { quality, and difficulty of making the extension on brand extension } \\
\text { evaluation, and compare between service vs. product domains. } \\
\text { P2P \& S2S brand extensions only. }\end{array}$ & $\begin{array}{l}\text { In a S2S context, consumers use complementarity with the original } \\
\text { category as a cue to evaluate extensions significantly more than in P2P } \\
\text { contexts. Substitutability has a less influential role in P2P (vs. S2S) } \\
\text { contexts; transferability is just as important in both contexts. } \\
\text { Parent brand quality influences brand extension evaluation directly. }\end{array}$ \\
\hline $\begin{array}{l}\text { Hem, de Chernatony, and Iversen } \\
(2003)\end{array}$ & $\begin{array}{l}\text { Investigate the impact of similarity, brand reputation, extension } \\
\text { category risk, and consumer innovativeness on extensions of } \\
\text { brands from FMCG, durable goods, \& service sectors into } \\
\text { categories in the same sectors. } \\
\text { P2P \& S2S extensions only. }\end{array}$ & $\begin{array}{l}\text { Across FMCG, durable goods, and service brands, category similarity } \\
\text { and brand reputation drive extension evaluations. Perceived extension } \\
\text { risk is only a significant driver for services and durable goods. } \\
\text { Consumer innovativeness is only a significant driver for services. }\end{array}$ \\
\hline Lei et al. (2004) & $\begin{array}{l}\text { Assess if an extension with relatively lower, compared to higher } \\
\text { service intensiveness than the parent brand, results in different } \\
\text { brand extension evaluation \& parent brand post-evaluation. } \\
\text { The paper uses service intensiveness, rather than the S vs. P } \\
\text { dichotomy. }\end{array}$ & $\begin{array}{l}\text { Evaluations are higher for less service intensive extensions compared } \\
\text { with more service intensive extensions, and the effect is stronger for } \\
\text { high similarity vs. low similarity brand extensions. } \\
\text { Contrary to predictions, parent brand post-evaluation is higher for less } \\
\text { service intensive extensions compared to more service intensive } \\
\text { extensions. The difference is significant only for high similarity } \\
\text { extensions. }\end{array}$ \\
\hline Martinez and Pina (2005) & $\begin{array}{l}\text { Propose a model of how potential consumers evaluate service } \\
\text { extensions. } \\
\text { S2S brand extensions only. }\end{array}$ & $\begin{array}{l}\text { Corporate image affects both perceived extension service quality and } \\
\text { the perceived fit between the new service and the parent brand, which } \\
\text { in turn affect attitudes toward the extension. }\end{array}$ \\
\hline van Riel and Ouwersloot (2005) & $\begin{array}{l}\text { Test the success of e-service brand extensions on a brand portal } \\
\text { site using Aaker and Keller's (1990) model. E-services are } \\
\text { compared against traditional services. } \\
\text { S2S brand extensions only. }\end{array}$ & $\begin{array}{l}\text { The results confirm Aaker and Keller's (1990) model for electronic } \\
\text { services. E-service extensions behave similarly to general services and } \\
\text { products; some subtle differences exist though. }\end{array}$ \\
\hline Pina et al. (2006) & $\begin{array}{l}\text { Analyze the influence of service brand extensions on corporate } \\
\text { brand image. } \\
\text { S2S brand extensions only. }\end{array}$ & $\begin{array}{l}\text { The fit between corporate brand and the service extension influences } \\
\text { the perceived quality of the S2S extension, which further affects } \\
\text { corporate image. This finding holds especially for corporate brands that } \\
\text { originally had highly rated images. }\end{array}$ \\
\hline
\end{tabular}




\begin{tabular}{|c|c|c|}
\hline Lei, de Ruyter, and Wetzels (2008) & $\begin{array}{l}\text { Examine consumer evaluations of vertical service line extensions } \\
\text { \& feedback effects on the parent brand. } \\
\text { S2S line extensions only. }\end{array}$ & $\begin{array}{l}\text { Consumers perceive higher risks in step-up versus step-down } \\
\text { extensions, which affects vertical line extension evaluations; this effect } \\
\text { is moderated by risk relievers, such as service guarantees or } \\
\text { consumers' prior knowledge in the service category. } \\
\text { The parent brand evaluation (i.e., the feedback effect) is more positive } \\
\text { after the introduction of a step-up compared to a step-down extension. }\end{array}$ \\
\hline Völckner et al. (2010) & $\begin{array}{l}\text { Analyze the impact of service brand quality (interaction, physical } \\
\text { environment, and outcome quality), extension fit and parent } \\
\text { brand conviction on service brand extension success (measured as } \\
\text { service extension quality). } \\
\text { S2S brand extensions only. }\end{array}$ & $\begin{array}{l}\text { Parent brand quality, rather than perceived fit between the brand and } \\
\text { the extension, is the dominant brand extension success factor. All three } \\
\text { dimensions of parent brand quality are distinct drivers; outcome quality } \\
\text { has the strongest impact on service extension success, followed by } \\
\text { physical environment quality and interaction quality. } \\
\text { Each parent brand quality dimension has the strongest impact on the } \\
\text { respective extension service quality dimension. }\end{array}$ \\
\hline Aksoy et al. (2011) & $\begin{array}{l}\text { Investigate the relationship between recommendation intentions } \\
\text { and new service brand extension adoption, depending on } \\
\text { customer recency of new service adoption \& frequency of contact } \\
\text { with potential users. } \\
\text { S2S brand extensions only. }\end{array}$ & $\begin{array}{l}\text { Recommendation intention predicts new service adoption by potential } \\
\text { customers only if recommending customers are more recent adopters of } \\
\text { the service, in more frequent contact with potential users. }\end{array}$ \\
\hline Boisvert (2012) & $\begin{array}{l}\text { Investigate how vertical service line extension direction } \\
\text { (downward vs. upward) and prior parent brand salience (low vs } \\
\text { high) impact parent brand evaluation, via transfer of image and } \\
\text { performance associations. } \\
\text { S2S line extensions only. }\end{array}$ & $\begin{array}{l}\text { Both the direction (upward vs. downward) of vertical service brand } \\
\text { extension and the contextual salience of the parent brand affect parent } \\
\text { brand evaluations directly by modifying the parent brand's image } \\
\text { associations. They also affect parent brand evaluations indirectly, by } \\
\text { modifying the parent brand's image and performance associations } \\
\text { through the mediating effect of the vertical extension's image and } \\
\text { performance associations. }\end{array}$ \\
\hline $\begin{array}{l}\text { Pina, Dall'Olmo Riley, and Lomax } \\
\text { (2013) }\end{array}$ & $\begin{array}{l}\text { Examine the impact of parent brand nature (S/P), extension } \\
\text { nature (S/P), extension fit and parent brand image (pre- } \\
\text { extension) on extension attitudes \& parent brand image (post- } \\
\text { extension) } \\
\text { Parent brands \& extensions of either service (S) or durable good } \\
\text { (P) natures }\end{array}$ & $\begin{array}{l}\text { No support for the impact of parent brand nature }(\mathrm{S} / \mathrm{P}) \text { or extension } \\
\text { nature }(\mathrm{S} / \mathrm{P}) \text { on attitudes toward the extension. } \\
\text { Support found for the nature of parent brand }(\mathrm{S} / \mathrm{P}) \text { influencing parent } \\
\text { brand image (post extension) directly and through its interaction with } \\
\text { fit. }\end{array}$ \\
\hline Sichtmann et al. (2017) & $\begin{array}{l}\text { Investigate how the effects of parent brand quality, parent brand } \\
\text { reliance, parent brand conviction, and consumer innovativeness } \\
\text { on perceived service brand extension quality depend on the nature } \\
\text { of the extension category (S/P). } \\
\text { S2S versus S2P brand extensions. }\end{array}$ & $\begin{array}{l}\text { Parent brand quality and brand reliance have stronger effects, while } \\
\text { parent brand conviction has weaker effects for S2S compared with S2P } \\
\text { brand extensions. }\end{array}$ \\
\hline
\end{tabular}


Appendix B - Manipulation of preliminary story in Study 4 (exemplified for HP)

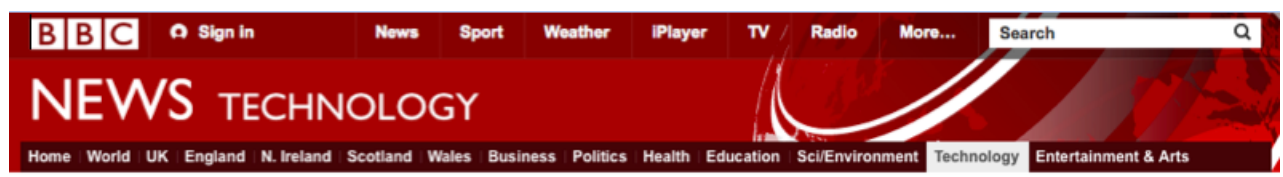

3 July 2014 Last updated at 18:29

<share $\mathbf{1} \square \square \mathrm{B}$

\section{HP to launch new product for technology device integration}

HP UK announced yesterday the launch of a new product for all British households, called HP Connector.

\section{Top Stories}

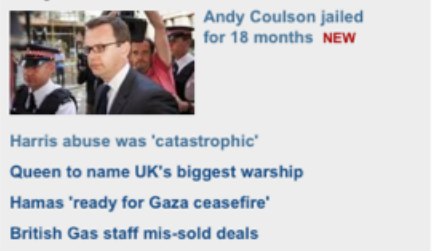

Most of us hold a variety of technology devices, including laptops, smartphones, tablets, cameras, TVs, printers or scanners, and the need for the seamless integration of such devices (e.g., for purposes of data transfer or device functioning synchronization) has never been bigger.

Customers will be able to order the new HP Connector rooter, that can installed in one's home along with the necessary technology and that can be programmed to achieve the best integration of one's technology devices (irrespectively of their brand or make).

The product will become available in the market in the coming weeks.

\section{PRODUCT STORY}

\section{B $|B| C$ Q sion in \\ NEWS TECHNOLOGY \\ 3 July 2014 Last updated at 18.29 \\ HP to launch new service for technology device integration}

HP UK announced yesterday the launch of a new service for all British households, called HP Connector.

Most of us hold a variety of technology devices, including laptops, smartphones, tablets, cameras, TVs, printers or scanners, and the need for the seamless integration of such devices (e.g., for purposes of data transfer or device functioning synchronization) has never been bigger.

The new service means customers will be able to book an appointment with an HP Connector team, who will pay a home visit to install the necessary technology and to advise on the best integration of one's technology devices (irrespectively of their brand or make).

The service will become available in the market in the coming weeks.

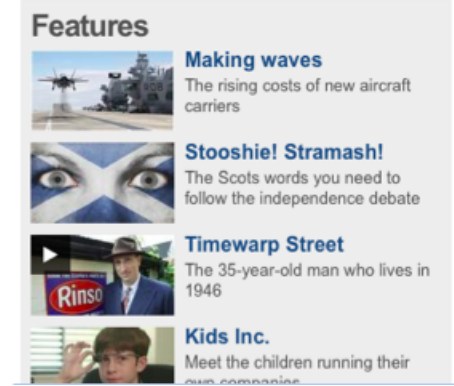


Appendix C - Logo design of Easy Pizza (relevant for Study 5)

\section{Passipratcom simply delicious \& delivered}

Appendix $D$ - Logos corresponding to the experimental conditions in Study 5

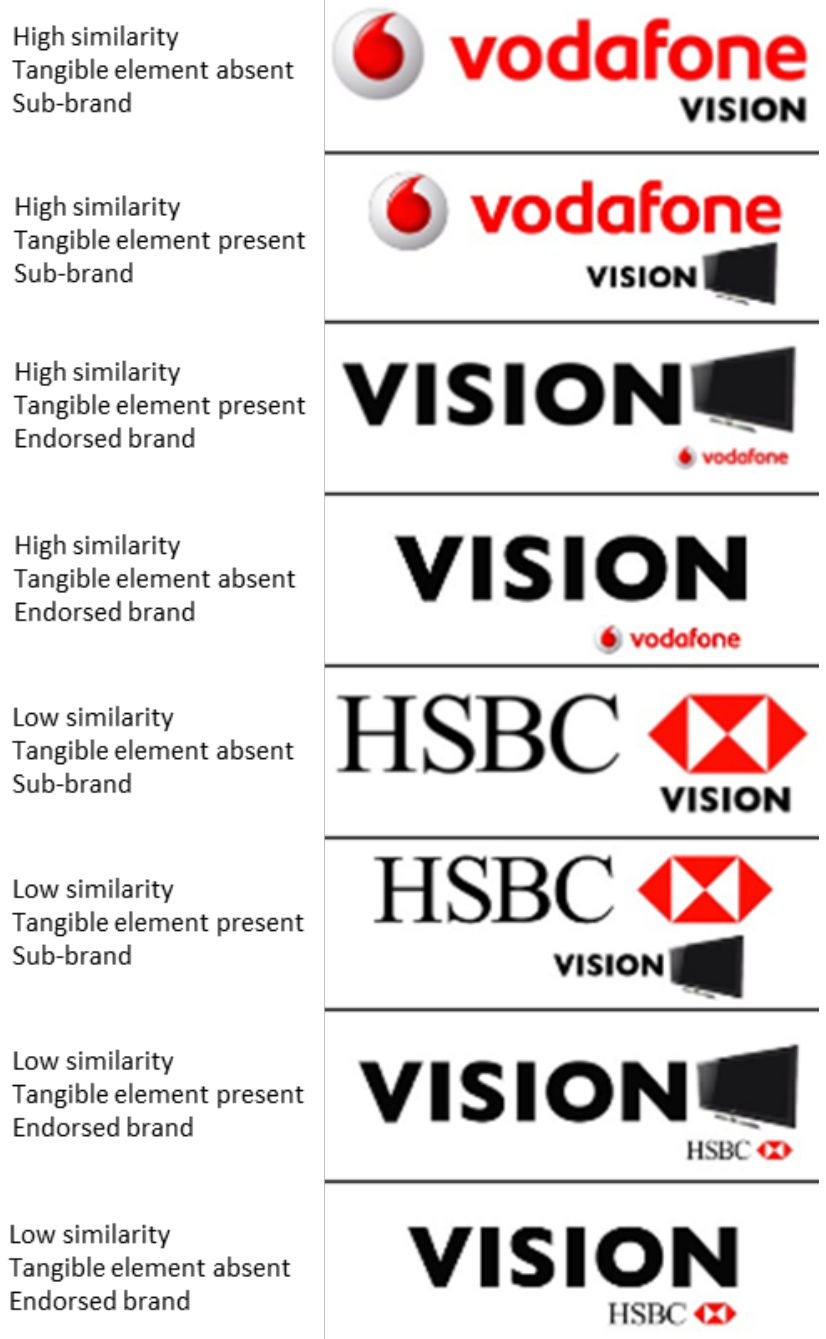

